\title{
THE ECONOMIC CO-OPERATION ORGANISATION (ECO): REALITY OR UTOPY?
}

Muzaffer Dartan*

\begin{abstract}
Turkey is fully integrated into the world economy. It has close bilateral and multilateral relations with many countries within the framework of international economic organisations. In other words, Turkey has always put emphasis on becoming part of regional economic organisations in order to develop its foreign trade and accelarate its economic growth. In particular, the disintegration of the Soviet Union created new opportunities for Turkey. Independent countries emerged in the southern part of the former Soviet Union which were receptive to the reactivation of bonds with Turkey rooted in their Muslim cultural tradition and, to a great extent, their affiliation to the family of Turkic peoples. The Economic Co-operation organisation (ECO) in whose establishment Turkey played an important role is a good example for that. The European Union (EU) also has an interest in the ECO region. A market with 355 million people, vast natural resources and a strong labour force makes the ECO of special interest to the EU. The integration of the $E C O$ is significant for the EU not only economically but also for reasons of security.
\end{abstract}

\section{Introduction}

The process of regional integration is gradually gaining importance in the world. Countries having common interests in a geographically proximate areas tend to set up regional economic and commercial associations. Turkey has taken part in such organisatons (see in the appendix I). The ECO is also one of them. This article discusses the prospects for regional economic co-operation within the ECO.

The next section focuses on the establishment process, aims and structure of the ECO, and its integrational advantages and constraints. The second section of this article describes the origins of ECO and its evolution.

*Assoc. Professor Dr., Marmara University, European Community Institute. 
The third section analyses the interests of regional powers (Russia and Iran) and the USA as a world power in the Caucasus and Central Asia. Since its expansion in 1992 to include six newly former Soviet republics, ECO has attracted the attention of those powers as it is a large regional organisation. That means the ECO covers today not only of the original ECO members but also the Caucasus and Central Asia, which are rich in natural resources and especially in oil and natural gas.

The fourth section deals with the role of Turkey within the ECO. The idea developed in the West that, after the disintegration of the Soviet Union, Turkey had an important role to play in the Caucasus and Central Asia - and especially among the Turk people living there. One central idea was that Turkey as a secular state in a Islamic society with a Western-style pluralistic-democratic system and a free market economy should be introduced as a "model" to the countries of both regions. However, Russia has tried to regain its lost political and economic influence in these regions. In particular, Russia does not want to lose control of the pipelines for transporting oil and gas to the world markets. In this respect, there is a big competiton between Russia and Turkey.

Against this background, this article looks first at Turkey's relations with Russia and the Turkic republics during the 1990s. The question is then raised as to whether the prospects for substantial intra-trade within the ECO are promising. A specific problem for Turkey is that she has a Customs Union with the EU. How does her Customs Union affect her trade with third countries as in the case of ECO? The article then deals with the question of whether Turkey can be a "bridge" between EU members and those of ECO and analyses possibilities for the transport of oil and natural gas from the Caspian basin via Turkey to world markets.

The article concludes with some remarks on the future perspectives of the ECO in general, and in particular the role of Turkey in the ECO.

\section{ECO as an Initiative for Regional Co-operation}

Turkey, Iran and Pakistan initially established this organisation as the "Regional Co-operation for Development" (RCD) in 1965. The RCD has not, so far, been a great success as neighbouring states never gave enough emphasis to trade. Industrial joint ventures were begun without giving enough thought to the barriers to trade that existed between neighbouring countries. With the collapse of the Soviet Union, the ECO was revived and in 1992 a conference took place in the Iranian capital, Tehran. In 1993, the 6 successor states of the former Soviet Union, that is Kazakhstan, Kyrgystan, Tajikistan, Turkmenistan, Uzbekistan and the trans-Caucasian state, Azerbaijan, participated in a follow- 
up conference in Quetta, Pakistan, together with Turkey, Iran, Pakistan, and Afghanistan (see Figure I).

Preliminary assessments of the ECO's economic significance may be organised into two broad categories. The proponents of the ECO denote its many strengths, including a 355 million strong population, vast natural resources and a sizeable labour force, arguing that the ECO has the necessary prerequisites to become a formidable economic force by the beginning of the $21 \mathrm{st}$ century. Those who fall into second category are more cautious about the ECO's minor significance at both regional and global levels. They advance two sets of arguments. First, the past performance of the ECO points to it remaining impotent as an economic bloc. Second, the existing political and ideological differences among its member states, most clearly exemplified by Iran's Islamic fundamentalism and Turkey's secular liberalism, will inevitably weaken the economic resolve of the Organisation, and hence its general performance. ${ }^{1}$

The RCD itself was a bi-product of the Central Treaty Organisation (CENTO). CENTO came into being out of the Baghdad Pact of 21 August 1959, and had its headquarters in Ankara. Mainly a defence pact against the Soviet Union, CENTO comprised Turkey, Iran, Pakistan and Great Britain, while the United States gained observer status and signed bilateral defence treaties with all three Middle Eastern member states. Although a defence organisation, CENTO also gained an economic dimension when it became deeply involved in development programmes centred on the development of transport, infrastructure and telecommunications. $^{2}$

In its first summit of the heads of state, held in July 1964, RCD members agreed to establish a secretariat and planning committees to study the following targeted objectives for tripartite co-operation:

- promotion of free trade;

- collaboration between chambers of commerce;

- formulation and implementation of joint-purpose projects financed by member countries;

- improvement of transportation and communication networks throughout the region;

- establishment of a shipping and joint maritime line;

- reduction of regional postal rates;

- promotion of tourism; and

- removal of visa restrictions. ${ }^{3}$

Despite a relatively elaborate bureaucratic machinery and sizeable personnel involvement from all three countries, the $\mathrm{RCD}$ 's record of economic 


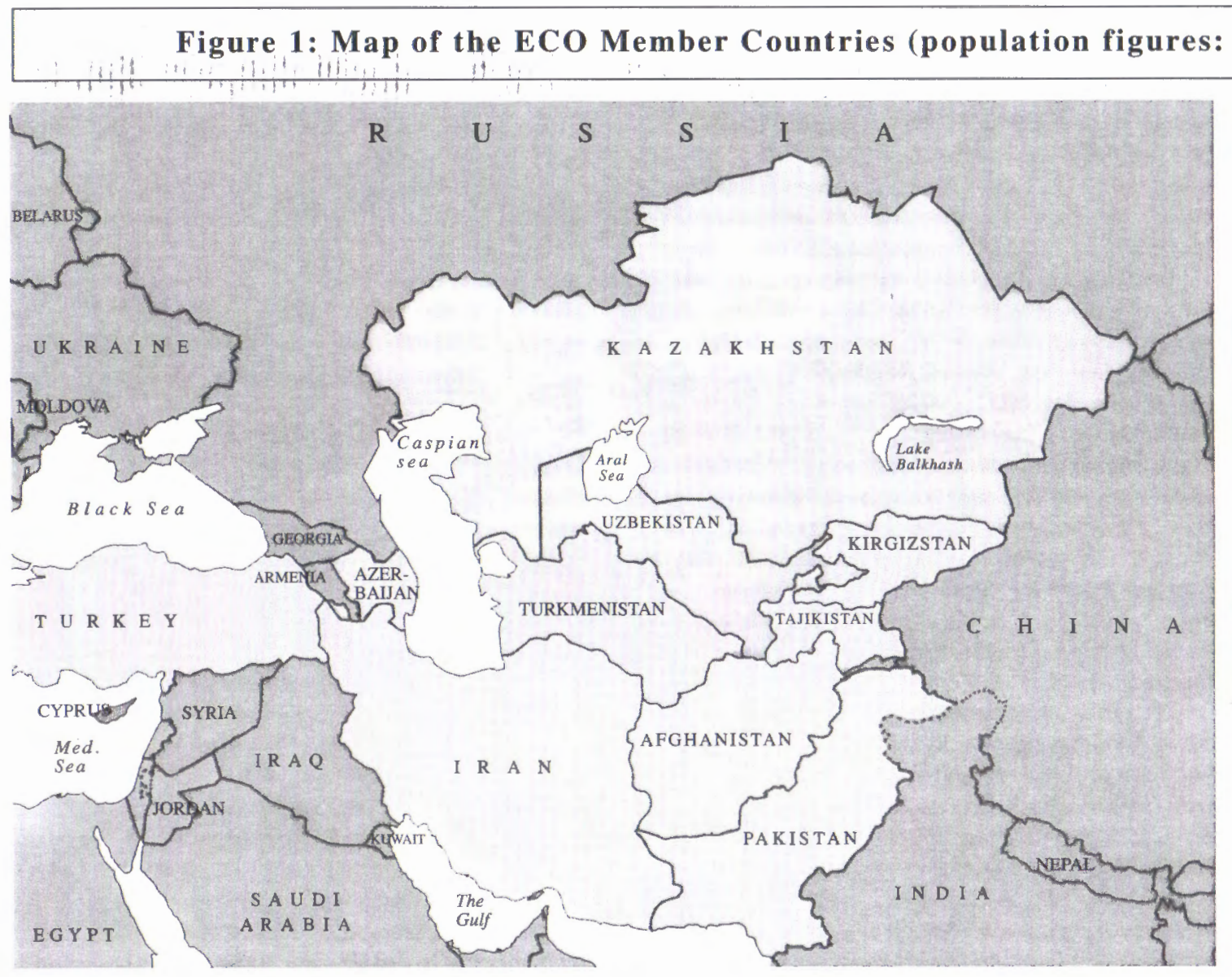

1998) 
accomplishments was less than impressive during the 1960s and negligible during the 1970s. In the final analysis, RCD's accomplishments were at best marginal and except for some early successes in telecommunication and transportation projects, failed to result in real economic gains for its member countries. The RCD became incapacitated by the late 1970 s as a tidal wave of revolution swept through Iran, political instability consumed Pakistan, and Turkey redirected its economic attention towards the European Community. Because of the political turmoil, these three states failed to establish the free trade area they had decided to form through the Izmir Agreement of 1976.

In 1985 the RCD states decided to reshape the organisational structure of the RCD and co-operate in the framework of a "preferential tariff agreement", renaming the organisation ECO. Beginning in early 1990 , however, ECO stepped up its activities in an effort to bring itself closer to the implementation stage of some of its targeted projects, particularly in the fields of trade, transportation, and communication. The break up of the Soviet Union and the subsequent emergence of independent states in Central Asia and the Caucasus provided an opportunity for ECO to expand its membership and its sphere of activities. Given the deteriorating economic conditions in the post-independence central Asia and Caucasus, and their common religious and cultural ties, especially with Turkey, Iran and Pakistan, the idea of an economic zone found considerable support in the region.

At the Tehran Summit of February 1992, the six successor states of the former Soviet Union applied for membership of ECO and their requests were granted. To these was added Afghanistan, which had recently thrown off Soviet occupation, raising the number of member states to ten. As a result, these ten member states laid the foundations of an economic region with 355 million people and an area of 7.9 million sq. kilometres ( 4.9 million sq. miles), about four times the land area of the European Union with a similar population.

\subsection{The Reasons for Establishment of the ECO}

The Tehran Summit was an important milestone, for it symbolised the aspirations and the options of the entire region. The Tehran Summit was intended to reactivate and extend the ECO. Moribund for more than a decade, the history of this regional organisation reflects the dramatic geo-strategic changes that had occurred in the region to date. Originally a product of the Cold War, ECO evolved into a framework for economic integration in a new Central Asia.

Of course, each member state is driven by its own national agenda with clear economic and political objectives that are designed primarily to fulfil national rather than regional aims. While one may argue that national and 
regional interests sometimes produce mutual benefits, it is national interest that has always been at the heart of any multilateral co-operation. In this respect, the creation of the ECO is no exception. All the new members seem to have somewhat lower levels of socio-economic development as compared to the original three members of ECO but, at the same time, they have rich and largely under-utilised natural resources that could be developed with outside help. The Central Asian republics have a highly educated work force that could usher in an era of accelerated development if financial preconditions are met in the region. What will most likely benefit each of ECO's members is the over 355 million strong market that could be developed if adequate attention were given to the development of transport and communication networks within the ECO region.

While economic interests played a significant role in the reactivation of $\mathrm{ECO}$, it would be naive to believe that only economic factors drove these nations to create such an organisation. National, regional, and international political objectives also played their part of the overall equation. For Iran, Islamic unity and independence has been an old objective and ECO is perceived by it as being a means to further that aim. Iran also wishes to use the countries to its north as catalysts to ending its long isolation. Turkey, on the other hand, is operating on the basis of its foreign policy concerns, particularly in connection with its relationship with the United States, to counterpoise Iran's perceived threat to the region. Turkey has spent huge sums in Central Asia to draw these republics closer to the West. For the Central Asian leaders, disenchantment with Russia and the other Slavic and Baltic republics (for both the imposition of severe trade restrictions, and the overall lack of sensitivity to their political and economic needs) has created the impetus to look elsewhere for partners.

It is now necessary to look at the historical development process of ECO in order to understand how Iran and Turkey came to reconcile their regional competition through attempts to co-operate within ECO? The principal forces behind this were the end Cold War and the emergence of no fewer than six new states in Central Asia.

Before 1979, the geopolitical codes of CENTO members were based on the containment of the Soviet Union through military and economic co-operation. After the Iranian revolution and the Soviet invasion in Afghanistan in 1979, things became somewhat more complex. Iran broke the Cold War pattern with its unique Islamic "neither East or West " philosophy, and Pakistan maintained an uneasy relationship with the United States as a frontline state against the Soviet occupantion of Afghanistan. Meanwhile, Turkey remained the closest "western" outpost against the Soviet Union and its unreliable Baathist clients in Iraq and Syria. In such circumstances, there was little room left for regional co-operation. 
After 1991, all three states were suddenly presented with the fait accompli of a complete geopolitical void - six newly independent states where the Soviet Union used to be, and total anarchy in Afghanistan. New geopolitical imperatives would now be based more on common interests than on the notion of an external threat.

- Firstly, Turkey and Pakistan lost some of their geo-political importance in the immediate aftermath of the end of the Cold War. Iran, which stubbornly and successfully maintained its independence from both the United States and the Soviet Union, ended up in an extremely uncertain and isolated position towards the end of the Cold War.

- Secondly, all three states had export-oriented industries and shared a common interest in the new markets opening up to the north.

- Thirdly, all three states had access to warm seas, while Azerbaijan, Afghanistan and the Central Asian republics do not.

- Fourthly, all three states shared ethnically overlapping borders and historical links with each other, and also with Afghanistan, Azerbaijan and the Central Asian republics.

- Finally, these common objective interests led to the need to co-ordinate regional competition between Iran and Turkey. ${ }^{4}$

\subsection{Aims and Structure}

The Tehran Summit was primarily aimed at the evaluation of the new political geography in Central Asia and reviewing possible ways of giving ECO new life and a new identity. The most important issue discussed at the Summit was the establishment of the Preferential Tariff System. A Protocol establishing the Preferential Tariff arrangement was signed on 23 May 1991 and was augmented by an Additional Protocol at the Tehran Summit on 17 February 1992). The Protocol provides for the liberalisation of trade among member states for a period of four years, automatically renewable for a period of another two years. The scope of Turkish concessions included a 10 per cent reduction on statutory rates for a number of products covering 37 tariff lines. ${ }^{5}$ The Protocol has a safeguard clause for balance of payments reasons and an accession clause for developing countries. Additionally, the summit participants discussed:

- The possibility of common regulation and co-ordination of air transport and the founding of an ECO air carrier;

- The founding of an ECO bank for trade and development;

- The co-ordination of maritime policies and oil exploration in the Caspian Sea; and

- Finally, the Summit participants also called for acceptable peace settlements 
in Nagorno-Karabakh, Afghanistan, Bosnia-Hercegovina, Palestine and Jammu-Kashmir. ${ }^{6}$

In 1995 a group of "eminent persons" was appointed to review the aims and structure of ECO in the light of the rapidly changing conditions in the world economy. Upon their recommendations, the Izmir Agreements were modified in September 1996. Through this revision, not only was the organisational structure modified but the decision-making process was altered, so that new changes would better contribute to the implementation of the envisaged objectives. The present ECO treaty contains the following objectives (For more details, see in the Appendix II):

- To expand trade among member states by providing freer access to each other's markets;

- To promote in each member state conditions for sustained economic growth in order to achieve continuous improvement in the standard of living of the people;

- To consolidate cultural affinities and spiritual and fraternal ties that bind the people of the member states through social and cultural channels of thought and action; and

- To contribute to the growth of world trade and to strive for removing iniquitous trading policies resulting in adverse terms of trade for the developing countries, by evolving a common approach in international fora.

It is clear that ECO's main aim is to establish a preferential trade system, rather than a free trade area. In fact, ECO was not conceived as a closed system, but rather as one which aspires to be open and to obtain a greater share of world trade. It is upon this principle that member states base their contractual relationships and work towards ensuring the fullest possible reduction of trade barriers in the ECO area. The experience gained within the ECO preferential tariff system will be invaluable in that respect.

It is noteworthy that, contrary to the RCD's mode of operation which was essentially government dominated, ECO is in favour of the active and largescale involvement of the private sector in economic development projects.

ECO's mandate and responsibilities are administered by the following organs (see Figure II):

Meetings of the Heads of State/Government: This is the chief organ of ECO. It meets twice a year or more often if necessary. Summits review the implementation of ECO programmes and projects and serve as a forum for exchanging views on regional and global issues of common interest to the ECO region. 


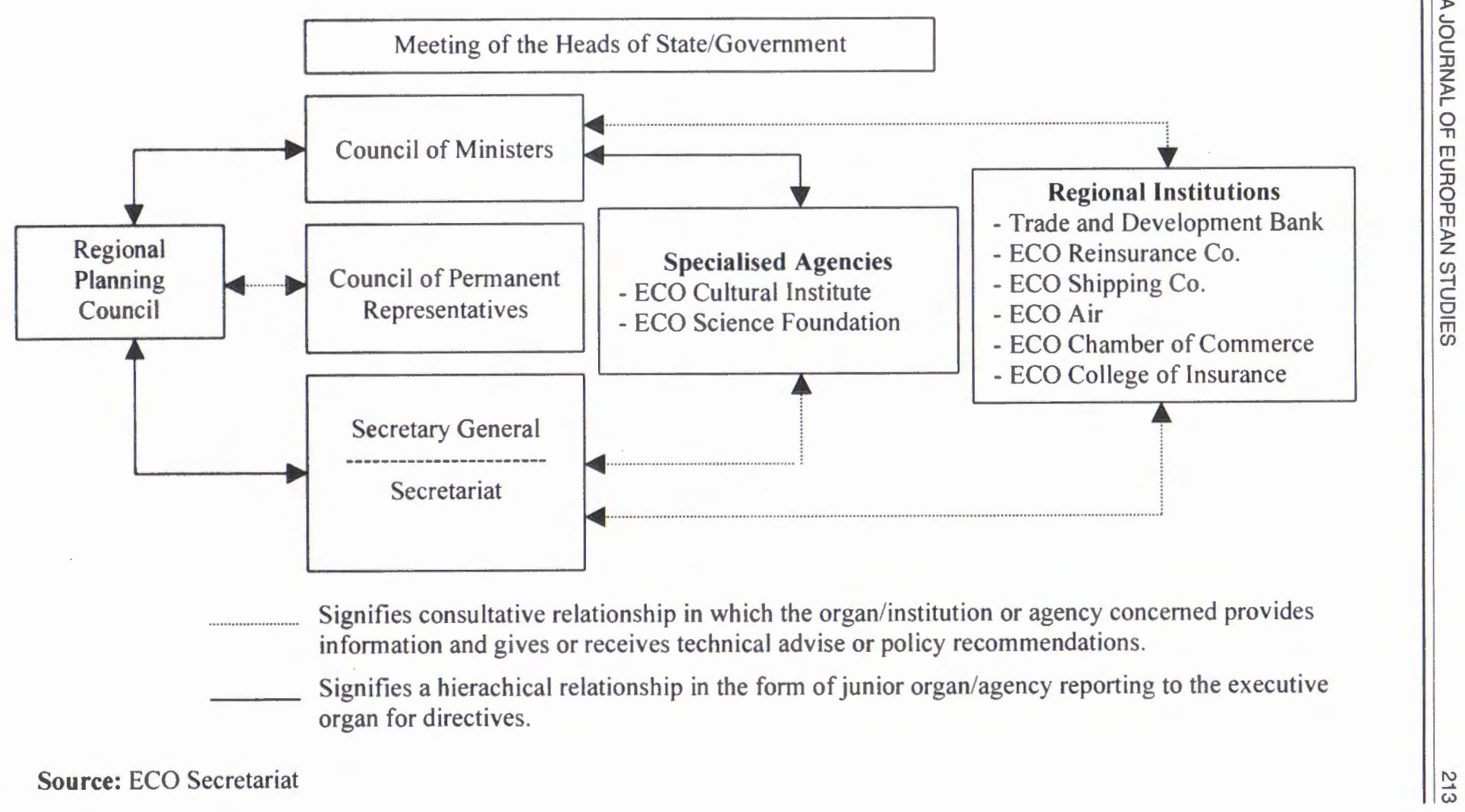


The Council of Ministers: This organ is the principal policy and decisionmaking body of ECO. It comprises the ministers of foreign affairs of member states and any other representatives of full ministerial rank as may be nominated by the governments. The Council meets at least once a year by rotation in the member states.

The Council of Permanent Representatives: This is a permanent body which, except when the Council of Ministers is in session, is responsible, on behalf and in the name of the Council of Ministers, for carrying out Council policies, for formulating issues requiring decisions by member states and for taking appropriate steps on matters connected with the implementation of the decisions of the Council of Ministers. It comprises the permanent representatives and/or ambassadors accredited to ECO.

The Regional Planning Council: The Regional Planning Council comprises the heads of the planning organisations of each member states and meets at least once a year at the headquarters of the organisation. It considers and develops programmes of action for realising ECO's. Draft programmes are submitted to the Council of Ministers for approval along with a review of past programmes and evaluation of results achieved.

The Secretariat: The Secretariat is headquartered in Teheran. Amongst the main functions of the Secretariat are:

- initiating plans and drawing up programmes of activities for submission to member states;

- maintaining contact with member governments with a view to following up the progress of implementation of Council of Ministers decisions and other matters relating to the organisation;

- acting as a clearing house for all matters relating to ECO; and

- acting as the information agency of ECO.

The Secretary General is the head of the Secretariat and is be appointed by the Council of Ministers. His tenure of office is four years and the post is rotated amongst member states.

Specialised Agencies: Agencies and institutions operate in some specific fields of co-operation.

Regional Institutions: These are economic, commercial and financial organs of ECO with self-sustained budgets and managerial autonomy. They aim to promote the economic growth of the ECO region through provision of financial and commercial facilities and investment of funds within the region. 
External Relationship of the ECO: Institutionalised co-operative relationships have been established with several UN agencies and other international organisations. Contacts have been established with UNESCO, the United Nations Fund for Population Activities, the Association of South East Asian Nations, the EU, the OIC and other organisations for pursuing common development objectives in the region. ECO was also accepted as an observer at the OIC and benefits from the activities of the Organisation for Economic Development and the Islamic Development Bank's facilities.

\subsection{Integration Assets}

The above mentioned figures are quite impressive but is ECO likely to succeed? Although ECO is still in its infancy and has not yet been much more than a forum for discussing the possibilities for regional co-operation, it is certainly a good instrument to developing certain regional assets - but how and in what field?

The three original ECO members have long coastlines in the Persian Gulf, Indian Ocean and Mediterranean. This offers alternative trading routes for the other seven members of the ECO, namely for landlocked Azerbaijan and the Central Asian republics, who are economically still heavily dependent on Russia, and Afghanistan. That is to say that transport and telecommunications are both key sectors in ECO, and that regional integration is an absolute priority if ECO is to succeed. The emphasis on the integration of transport and telecommunications was demonstrated by the "ECO Action Plan" drawn up at the summit of Quetta on 13 February 1993. This plan provides for:

- linkage of cross-border roads and railways;

- establishment of air links between all the capitals of the member states;

- linkage of telecommunications and power networks;

- unification of visa regulations, tariffs and custom formalities; and

- establishment of a trade and development bank. The bank has its headquarters in Tehran and disposes of a US\$400 million dollar fund. Its main purpose is to finance joint ventures between companies and governments of the founding states and those of the new members, again with an emphasis on transport infrastructure and telecommunications. ${ }^{7}$

Road integration is a basic pre-condition to fully develop the potential combined market for export oriented economies such as those of Turkey, Iran and Pakistan. Whilst these countries' domestic markets are growing (especially in Turkey and Pakistan), increasing protectionism in the European Union and the United States force countries like Turkey, Iran and Pakistan to search for new export markets. In this context the emergence of the new Central Asian 
republics was an excellent opportunity. It is not by accident that one of the first measures at the Tehran Summit was to work out tariff reductions for a set of industrial goods. In 1993, for example, the share of the manufacturing sector in the gross national product of Iran was 23 per cent, while for Turkey it was 31.5 per cent and for Pakistan it was 18 per cent. $^{8}$

On the other hand, the Central Asian republics were mere exporters of raw materials, while food and consumer goods came mainly from the Russian Federation. The Soviet industrialisation policy had its impact on the sectoral structure of the economies of the Cenral Asian republics. As a result of that policy, industrial development in those countries has lagged noticeably behind that in other parts of the Soviet Union. Approximately 80 per cent of the national industrial production and energy consumption was located in the European zone, although this area was poorly supplied with resources such as energy, minerals and raw materials. ${ }^{9}$ Soviet Asia had the bulk of the resources, but only a small share of industrial production. Central Asia's fuel industry consists of gas, oil, oil refining and coal. The high rate of development in gas and petroleum has turned this region into one of the primary energy bases for the Soviet Union.

Central Asia has also been the cotton base of the Soviet Union, and cotton development was always given the highest priority. In Uzbekistan, the cotton industry produced a high percentage of that country's gross output. In 1989, for example, Uzbekistan produced 5.2 million tonnes of cotton or 64 per cent of Soviet production, along with about the same amount of other crops. Nearly 85 per cent of Uzbek cotton was exported to be treated in the Russian Federation, while most machinery and consumer goods were also imported from the USSR ${ }^{10}$ It was the same for the raw materials of other Central Asian republics. This is to say that their economic dependency on Russia was (and remains) very high.

The same picture can also be seen from the data on Russian qualified employees for 1989 in the industries of Central Asian republics. For example, when Uzbekistan declared independence in 1991, it was the country with the greatest population among the Central Asian republics. Its population was over 20 million of which $71 \%$ is Uzbek, $8 \%$ is Russian, $5 \%$ is Tajik and the remainder of different nationalities. In 1991, 53\% of Uzbeks worked in the agricultural sector (mostly in the cotton sector) while only $2.5 \%$ of Russians were working in the same sector. On the other hand, whilst $11 \%$ of Uzbeks worked in industry, the ratio was $33 \%$ for the Russians. This ratio was even higher in certain industries. For example, more than $60 \%$ of the qualified employees in the chemical industry were Russian. A constant Russian emmigration is taking place from the Central Asian republics. The situation 
may be considered as a positive factor for the region at first glance, because the Russian population will decrease in the region and the ethnic problem will be reduced. However, considering the implications of this fact on the countries concerned, this idea is too optimistic. The workforce is highly qualified and its outward mobility imposes a serious pressure on the economies of the Central Asian republics. ${ }^{11}$

Is the ECO supposed to radically cut back this dependency? Surely, the answer is no. But it can offer potential alternatives that, in their turn, can make Central Asian republics less dependent economically on their huge northern neighbour. At the same time, it offers the new republics far more advantageous trade via warm seas (among Turkey, Iran and Pakistan).

These potential markets bring us to another of ECO's principal aims, namely the desire to develop an increasing degree of regional economic independence. Through regional integration, ECO states can develop and combine their respective comparative advantages in order to achieve a more efficient distribution of their production. Of course, the economies of the former Soviet republics were developed along such lines, but in a way which was submissive towards the centre. In ECO, this process is achieved on a voluntary and equitable basis. The possibilities for ECO are many and varied, as the following examples demonstrate. One of the most important of these is the export of oil and natural gas from the landlocked Central Asian republics through ECO members which are not landlocked, such as the planned project for carrying Azeri oil through a pipeline to the Turkish port of Ceyhan in the Mediterranean and then by tankers to world markets. Pipeline connections such as this would surely improve relations between ECO members. For example, whilst the Central Asian republics concentrate on developing their energy sectors in conjunction with other industrial sectors such as the petro-chemical industry, the three origin members of ECO may supply them, in turn, with consumer goods. ${ }^{12}$

Another possibility for co-operation between members would be ECO's role as a forum for the discussion and co-ordination of effective measures in relation to cross-border problems such as smuggling and drug and arms traficking, the spill-over of ethnic conflicts and refugees and ecological damage. An example of dramatic ecological damage is the shrinking of the Aral Sea and the rising water level and heavy pollution of the Caspian Sea, a major concern for many ECO states. Radical ecological measures would have far-reaching consequences in regional politics as, for access to fresh water increasingly becomes a major geopolitical problem. This is especially true for Uzbekistan, whose cotton economy depends almost entirely on irrigated land. There have been diplomatic tussles between Kazakhstan and Uzbekistan because of the latter's claims on 
water reserves in the Kazakh regions of Djambul, Chimkent and Aqmeshet (formerly Kyzyl Orda). The rising water level of the Caspian Sea floods fertile agricultural land in Azerbaijan and northern Iran, and is likely to cause refugee problems and agricultural decline in both states. Moreover, the heavy industrial pollution of the River Volga (which provides 78 per cent of the Caspian's water), obsolete offshore oil drilling and over-fishing, threatens fishery and caviar production, and thus a major export commodity for both Iran and Kazakhstan. ${ }^{13}$

\subsection{Integration constraints}

So then, ECO certainly has the potential to make itself a useful and purposeful regional organisation. Nevertheless, this potential is jeopardised by several factors which hinder ECO ambitions for serious economic integration modelled on the European Union.

The most striking feature of ECO is that it contains only groups of Islamic countries, or at least countries with an Islamic majority amongst their populations. For this reason, the organisation is often distrusted by the West as a potential "fundamentalist bloc" in the heart of Asia. Such reproaches are wide of the mark, however. Firstly, no-one sensibly supposes that the European Union, comprised as it is of predominantly Christian states, is a threat to the Islamic world. Secondly, ECO lives up to its name. It is, above all, an economic organisation based on very down-to-earth interests that have nothing to do with the export of revolutionary ideology. A common Islamic culture does not mean, however, that that there are no important disagreements between ECO states on which direction ECO should take. Those disagreements lie along TurkishIranian lines. ${ }^{14}$

Turkey and Iran have long vied with one another for influence in Central Asia. In ECO, this rivalry manifests itself as a disagreement as to which direction to take. Turkey considers ECO merely as an economic organisation modelled on NAFTA. Iran imports to it a cultural and security component, something akin to an Islamic Commonwealth along similar lines to ASEAN. For so long as this rivalry persists, ECO is more likely to remain, in the medium to long term, a regional trade forum more than anything else. Another important factor which supports the view that ECO is unlikely to become an "Islamic bloc" is the complexion of the governments in the Central Asian republics. After the collapse of the Soviet Union, the old nomenclatura largely remained in power, despite the name changes of their parties and the secret police. Accordingly, the elite of those republics have more in common with their Moscow counterparts than with those in the three original member states of ECO. After the collapse of the Soviet Union, each Central Asian republic signed bilateral agreements 
in different fields. On 30 May 1992, for instance, the Russian Federation and Uzbekistan signed the "Treaty for Inter-States Relations, Friendship and Cooperation", which envisages economic co-operation and a common military strategic region. A Russian-Uzbek axis could be lethal for ECO, particularly if Uzbekistan decides to abandon its path and opts instead to fall back within the Russian orbit. It is no secret that Moscow is displeased with ECO, as it still sees it as a rival to its power in the region. A successful ECO would certainly curb Russian influence in this part of its "near abroad".

It should not be forgotten that Turkey also plays an important role in Central Asia. With the exceptions of Tajikistan and Afghanistan, Turkey has very close cultural ties with the other new members of ECO, which are not only Islamic oriented states but also of Turkish origin. The important point is that Turkey is a secular state. Accordingly, Turkey's position in ECO (with the support of the other Turkic republics) prevents ECO being characterised by Islamic motives.

Under these circumstances it can be said that the success of ECO depends only on economic criteria. It is unlikely that ECO will fail. In other words, the Central Asian republics have a common problem in that they remain in a transition process to a market economy. That process is necessary for the integration of these states into the world economy. These republics are making great efforts to market their rich natural resources through co-operation with multinational energy companies. On the other hand, Turkey, Iran and Pakistan, being developing countries, also need to increase their trade volumes on the world market. This, more than anything else, is symptomatic of the new reality in Central Asia. This reality is far more complex and urgent than any struggle between "religious obscurantism" and "secular modernity".

The former Soviet Central Asian republics display certain characteristics which differentiate them from other ex-Soviet states:

i) They are far inferior both in economic and military terms to the dominant regional power, Russia, as they have similar populations. Even Uzbekistan, which aspires to the role of leading regional power in Central Asia, has just under 23 million inhabitants compared with 148 million in Russia. Uzbekistan's gross domestic product amounts to just 7 per cent of the Russian figure. ${ }^{15}$ Above all, and it is here that these countries differ to an even greater extent from those successor states in the west of the former Soviet Union, they belong, despite certain modernisation successes during the Soviet period (localised industrialisation, literacy improvement), to the category of developing countries. That is, they suffer from elementary deficiencies, such as the shortage of water and land and the extreme poverty of large sections of the population creating a volatile social situation. 
ii) In the event of conflict none of the countries can count on Western protection that extends beyond the peacekeeping missions of international organisations. Although the region no longer belongs, as in the days of the former Soviet Union, to an exclusively Russian sphere of influence, neither is it part, like central and eastern Europe, of an area tacitly protected by the West.

iii) The existence of these states could be jeopardised through internal conflicts such as separatist activities and conflicts between ethnic groups. No demarcation of borders, certainly not of Soviet borders, can lead to a neat separation into ethnically pure nation-states - Russian and Ukrainian sections of the population are disregarded in this respect. A risk of "ethnic cleansing", as between Azerbaijan and Armenia during Nagorny-Karabakh conflict, could also emerge between Uzbekistan, Tajikistan and Kyrgyzstan if existing ideas, for example, of a "Greater Uzbekistan" or a "Greater Tajikistan", were realised.

iv) None of these states has access to the open sea, which makes them vulnerable to transport blockades. The railway connections and pipelines are orientated to the industrial centres of central Russia and of the Urals, whereas the extension of corresponding links in other directions - to Turkey, Iran and China - has only just begun.

Unlike other co-operative efforts in Central Asia, ECO has a very low probability of success. Rather than viewing ECO as a bona fide forum for regional co-operation, its three most important members have been attempting to use this body to advance their countries' interests in the Central Asian successor states of the Soviet Union. From very beginning, Iran has emphasised the Islamic nature of ECO and maintained that this organisation could represent the first step towards a common Islamic market. Turkey, however, has been opposed to placing such emphasis on the Islamic character of ECO.

Ignoring, for the moment, the issue of religion, the poor prospects for the future of ECO become apparent upon taking a second look at the organisation. The differences between the participating countries are too great to make them good candidates for a regional co-operation project. Successful regional integration can only be achieved if the countries involved possess a minimum of economic, cultural and political common ground.

Currently, all Central Asian countries are experiencing serious transformation crises of varying degrees, resulting in the relatively low probability that any one country could gain an advantage over the remaining countries of this region due to a position of economic superiority. Therefore, it would be a mistake to wait until these transformation processes have been completed, by which time these countries may be faced with the difficult task of effecting co-operation between highly divergent economies. 
Conversely, it must be noted that the relatively similar economic structure of the Central Asian countries also presents certain disadvantages. The experiences of the countries of the south have shown that integration projects frequently fail because the economies of the countries involved are too similar and do not sufficiently complement each other.

Considering these aspects in their entirety, a greater risk results from internal and external conflicts and the greater likelihood of military and economic intervention by external powers. This makes the question of internal and external security even more pressing for the southern successor states of the former Soviet Union. The following foreign and security policy variants would seem, in principle, conceivable for these countries:

- A common international alliance, that is, in this case, the Commonwealth of Independent States (CIS) - the member states of the CIS are: Russia, Armenia, Azerbaijan, Belarus, Georgia, Kazakstan, Kyrgyzstan, Moldova, Tajikistan, Turkmenistan, Ukraine, Uzbekistan;

- An alliance (or several alliances) without Russia solely between the southern CIS states;

- Neutrality or a separate foreign policy path;

- An alliance with another major regional power, which means, depending on circumstance, the West (including or excluding Turkey), Iran or China as possible alliance partners. ${ }^{16}$

Inside the CIS, Moscow not only sets the general framework for economic and military policy but also external relations. Moscow wishes that the CIS should be developed into an economically politically integrated "influential regional power". ${ }^{17}$ In reality, however, the CIS is an institution in which bilateral relations with Russia and between individual member states prevail. There can be no talk of a foreign policy decided on the basis of common consultation.

The Central Asian republics, in common with other ex-Soviet republics, also joined the CIS. Up until now, Russia and Belarus have viewed the CIS as a mechanism to recreate a version of the Soviet Empire. Kyrgyzstan, Armenia and Tajikistan have viewed the CIS as a means to garner Russian military assistance. Moldova, Kazakhstan, Turkmenistan and Ukraine, forced to affiliate with Russia for economic reasons, see the CIS as a necessary evil to be endured. Georgia and Azerbaijan - which were also forced into the organisation - have doggedly tried to dilute the CIS's institutions whenever possible in order to lessen Russian influence. However, the new Putin government in Russia used the last CIS summit in Moscow to transform the CIS from a weak organisation filled with belligerent members into a coherent organisation. For example, 
Russia has tried to re-integrate the Georgia-Ukraine-Uzbekistan-AzerbaijanMoldova (GUUAM) group, which was specifically formed to counter Russian hegemony. ${ }^{18}$

Regional integration approaches can claim some significance inside the CIS. It is telling, however, that this area of Central Asia has not formed any meaningful alliances. Various associations currently exist which only include parts of the region. Since January 1995, a Customs Union has existed between Belarus, Russia and Kazakhstan, to which Kirghiztan acceded in March 1996. The Central Asian Economic Community (CAEC) (which, prior to July 1998 was known as the Central Asian Union) was established in December 1994, comprising Kazakhstan, Kirghiztan, Uzbekistan and latterly Tajikistan (which was granted entry in March 1998).

In view of the possible internal and external risks, it would be reckless for the countries in this region to rely on the principle of neutrality and the desire for good relations all round.

It is a fourth option, namely the formation of alliances, which is being realised. As a further examination demonstrates, the states tend to support one of the two alternatives "West/Turkey" or "Russia/Iran". A mainly Western/Turkish foreign policy orientation can be discerned in Azerbaijan, Kazakhstan, Kirghistan and Uzbekistan. On the other hand, Armenia, Turkmenistan, and Tajikistan are orientated more towards to Russia/Iran.

\section{Position of regional powers and USA towards Central Asia and the Caucasus}

In order analyse the position of Turkey in Central Asia and the Caucasus correctly, it is necessary to look at the position of Russia and Iran as regional powers, and the USA as a world power.

\subsection{Russia's Position}

In the Caucasus and Central Asia, Russia has concentrated on three principal fronts:

In order to control the region, the Russia government has worked to:

- ensure that no pipelines are built which bypass Russian control;

- coerce former Soviet republics into co-operation; and

- deepen an extraordinarily subtle, important, and fragile relationship with Iran. 
In relation to oil and gas pipelines, Russian public statements are unequivocal - the oil and gas resources of the region must flow via Russia to world markets. The geopolitical consequences of the success of this policy are obvious:

i) the instability, violence and conflict that have characterised the newly independent ex-Soviet republics (much of it instigated by Moscow itself) has led Moscow to hope that it might be able to control these new states. However, Moscow cannot hope to achieve this without also somehow gaining influence with the Gulf States and, especially, Iran whose location offers the former Soviet republics access to the sea and to the world. If Russia could succeed in its ambition, it could conceivably put together a new pact of oil-producing countries that might regulate the market with mere pronouncements, much as OPEC was once able to do;

ii) Russia would easily be able to bring sufficient pressure to bear to cause the newly independent Caucasian and Central Asian states to distance themselves from the USA;

iii) Russia would be able to prevent America and her surrogates, such as Turkey, from exercising influence anywhere in the Caucasus and Central Asia;

iv) Russia could more easily coerce larger subsidies from the funding programmes of wealthy states such as the EU;

v) Russia would also need to be included in important decisions on strategy and politics in Central Asia. (In other words, Russia would remain as one of the most important decision-makers in Central Asia, as it was before the collapse of the Soviet Union). ${ }^{19}$

Both Russia and Iran oppose American and Turkish influence in the Caucasus and Central Asia. Iran has supported Russia's basic position with regard to the development of the energy resources of the Caspian Sea, namely joint development by the five littoral states. In practice, joint development means that Russia, which has little Caspian energy, would have a say in the disposition of the resources of more richly endowed countries. Why Russia is content with this arrangement is clear but why should Iran seek to foster the hegemony of its huge neighbour over its smaller neighbours?

The answers are not wholly satisfactory. With some 6-12 million Azeris living in Iran, a Russian dominated/controlled Azerbaijan would lessen the perceived drive of Azeri separatists in Iran to link up with their kinfolk in Azerbaijan. On the other hand, Iranians remember that when the Soviet Union was strong, Moscow used the Azeri minority in Iran as a fifth column. The 
main reason why so many Iranians are willing to collaborate with the Russians is a reflexive hatred of the US. Iranians usually think that the US oil companies' presence in the Caspian Sea is aimed at paving the way for a US military presence in this sensitive oil rich region. This view, of course, neglects the fact that Russia is also militarily present in the region, and as long as it remains there it can curtail Iranian independence far more efectively than America ever could. ${ }^{20}$

Russia masks its inherent threat to Iranian independence by selling ballistic missile components, a nuclear programme and advanced military equipment (such as the Kilo-class submarine) to Iran. Some in Iran argue loudly that this equipment is making Iran into a major regional power. Nothing could be further from the truth. This equipment is good for only one purpose: frightening the Americans and Israelis with the possibility of terror-type attacks. Even armed with nuclear weapons, the Iranian missile force could not be part of a successful military campaign against a European country, much less the US. Nor could such a force prevent America from occupying Iran. Indeed, the only country in the world that could possibly occupy Iran is Russia quickly wiping out Iran's missiles prior to an invasion. But Iran's possession of missiles and nuclear warheads to put on them succeeds fully in alienating America from Iran.

Russia lso makes money in Iran. Increasing trade between the two countries particularly in the energy sector, was highlighted by two Iranian-Russian agreements in April 1998 for a joint drilling project in Iran's continental shelf and direct investment by the Russian state gas monopoly, Gazprom. Trade will be further enhanced through the building of a new $\$ 1.5$ billion merchant port complex on the Caspian Sea in Southern Russia. Russia and Iran intend to form a joint venture to complete port construction and establish a ferry link between the two countries. ${ }^{21}$ It seems that Moscow has persuaded the Iranians that both can use their dominance over their neighbouring states of the region to purchase their energy products at below world market prices and then sell them on to the comsuming nations of Europe and Asia. This would also provide opportunity to extort political concessions from countries such as Turkey who may come to rely on lucrative transit revenues.

\subsection{Iran's Position}

With its location and policy relations, Iran is one of the key countries in determining security and stability in Central Asia. Iran and Russia are cooperating on a north-south axis against the co-operation of Turkey and Azerbaijan, and, in a more general sense, against the USA's co-operation with Azerbaijan, Israel and Turkey. With the agreement that was signed between Russia and Iran in April 1998, energy co-operation was initiated between them. This co- 
operation includes managing common energy policies in the Caspian and Caucasian region.

One of the main reasons for an intensive co-operation in the field of energy is that until 1991, the Caspian Sea was shared by the Soviet Union and Iran under the terms of the Treaty of Moscow, 1921. Since the break-up of the Soiet Union, a dispute has arisen as to who actually owns the seabed, beneath which lies the oil. Russia and Iran, with little oil directly off their coasts, contend that the seabed should be the joint property of all the littoral states. Kazakhstan and Azerbaijan, with the largest oilfields right on their doorsteps, have most to lose from such an arrangement and would prefer a different division. Azerbaijan has been the main proponent of a division of the Caspian along national lines. The Iranians would lose most from the Azeri plan because of the paucity of fields off their shores. Russia would not be so badly off because it already possesses substantial fields on its Caspian shores, but Russia gibs at losing so much potential wealth to the newly independent states. ${ }^{22}$

The US has resisted the passage of any pipeline through Iran as a means of distributing Central Asian resources to world markets. As known, In addition to this, Iran aims to implement its own style of governmentin the Turkic republics and especially within the non-Turkic countries of Central Asia and to integrate of these countries into its sphere of influence.

\subsection{The Position of the USA}

In order to compete for influence with Russia in the Caucasus and Central Asia, the US has concentrated on at least five foreign policy objectives:

i) to make sure that multiple pipelines are built, and that one of them leads from Baku to the Turkish port of Ceyhan. This alone would remove a powerful Russian pressure point. Of course, making sure of this would require giving the oil companies a subsidy to build a facility whose cost cannot be fully justified economically, though it can be justified strategically and strategy is the government's busines;

ii) to prevent the Russian-Iranian entente from flowering into a strategic alliance. This is a tall order for so long as the US regards the Iranian regime as religious fanatics. In fact, as Russia has shown, it is entirely possible to deal with the Islamic republic on a thoroughly secular basis. The US has much to offer Iran both in terms of geopolitical and economic advantage. Accordingly, the US should be trying to improve relations with Iran;

iii) to safeguard the role of Turkey in the region. American policy makers must continue to remind themselves that Turkey is the most important country 
in Euroasia. Every dollar spent defending and consolidating Turkish power in the region is likely to save many times that in American blood and resources. By virtue of its location, history, and ethnicity Turkey can counterbalance Russia in ways that America cannot. Relations between America and Azerbaijan need to be normalised, thereby facilitating a strategic land bridge between the Caspian and the Mediterranean.

iv) A US supported alliance system anchored in Turkey, Israel and Jordan would offerthe benefits of market democracy and collective security and would amplify the incentive for the belligerent southern Caucasus states to reach a settlement and reject the embraces of their Russian neighbours. The policy of pushing Israel into a position of military vulnerability, especially in relation to Russian clients like Syria, should be reversed. As much as possible should be done to cement Israeli-Turkish ties; and

v) to deny the Russians forward deployment of troops on the southern rim of the Caucasus at a radius of 500 miles or so from to the oil fields of Iraq and the Gulf. Here again, the US would need to deter Russia with its current economic leverage. If the economic independence of the former Soviet republics is secured, if Turkey is strengthened and Iran neutralised, and if Saddam Hussein can be rolled back and President Asad cowed, the US should have no trouble maintaining its alliances in the Persian Gulf. In that case, Russia would have no reason to attempt to deploy troops on the southern rim of the Caspian. ${ }^{23}$

\section{Turkey's Position towards Central Asia and the Caucasus and its Role within the ECO}

\subsection{Turkish-Russian Relations}

With the fall of the Soviet Union in 1991, a new era began in TurkishRussian relations. These relations, which historically have witnessed many political disputes and military conflicts, saw raproachment during the 1920s, when both countries were founded. Due to its security concerns, Turkey became a part of the Western bloc by joining NATO when the Soviet Union showed its intention to demand land from Turkey after World War II. After 1945, during the Cold War era, Turkish-Soviet relations were shaped to the extent that the bipolar world permitted. During the 1960 s, however, economic relations improved and the two countries were in a distant but relatively co-operative relationship until Soviet leader Mikhail Gorbatchev introduced perestroika in the mid-80s.

In 1984, the Natural Gas Treaty was signed by Turkey and the USSR, and the economic dimension left its mark on Turkish-Russian relations and from 
then on economic relations between the two countries have progressed independently of political relations. Today, the contents of Turkish-Russian relations are predominantly economic. Yet it is not possible for even economic relations to grow stronger so long as political disputes exist. Economic relations are a major and developing area of collaboration between the two countries. Official and non-official trade boomed between Turkey and Russia in the wake of the 1984 Natural Gas Treaty. The liberal economic policies the Soviet Union also became apparent at about that time. From 1997, the Russian federation was Turkey's second major trade partner and second biggest export market after Germany. In 1997, Turkey's exports to Russia were approximately $\$ 2$ billion and imports around $\$ 2$ billion. When you add the suitcase trade and construction contracts, total trade amounted to some $\$ 8-10$ billion. ${ }^{24}$

Maintaining good economic relations is important for both Turkey and Russia. For example, Turkish construction firms enjoy a 50 per cent market share in foreign construction contracts in the Russian Federation. In other words, one of the most important yardsticks of economic relations between Turkey and Russia, are construction projects. In 1997, the volume of such projects undertaken by Turkish firms in the CIS was $\$ 8.5$ billion - about half of which had been completed so far. The proportion of these projects which have been launched in Russia was $\$ 6.1$ billion. Of those, some $\$ 3.5$ billion have been completed. The total number of projects undertaken in the CIS by Turkish firms is around 375 . Nearly 250 of them are in Russia, and many of the remainder in Turkmenistan and Kazakhstan..$^{25}$

The fact that Russia is still in the process of forming a modern economy and lacks the necessary infrastructure creates many problems for Turkish firms operating there. In the light of the worldwide economic crisis of 1998, Turkish firms need some kind of export indemnity insurance from the Russian government and should be given incentives to do business in Russia, for example, loans from Eximbank. When one considers that 13-15 percent of Turkey's total annual foreign exchange income comes from trade with Russia, Russia's long lasting economic crisis has taken a heavy toll on Turkey.

The energy sector is an area where there is both co-operation and competititon between Turkey and Russia. Russia supplies a major part of Turkey's natural gas requirements. This will increase with the realisation of the Blue Stream project - an underwater gas pipeline that would double gas supplies to Turkey - at the beginning of this century. However, the two countries are competing for the pipelines that will carry Caspian oil to the West. Russia's two main claims on the pipelines are; firstly to control the point of export of oil so it may be used as a weapon against the Middle east and Azerbaijan; and, secondly, to control the price of oil. 
The major factors affecting economic and political relations between Russia and Turkey are:

- how disagreements between Turkey and Russia on the usage of oil and natural gas resources naerby are resolved; and

- Turkey's level of usage of Russian based energy sources.

Russia, as Turkey's main gas supplier, is currently contracted to sell Turkey 14 billion cubic meters of gas annualy. Turkey uses 58 per cent of its imported gas to generate electricity. The share of used natural gas in the electricity production in Turkey has been growing continuously since the 1990s. For example, its share of the whole of electricity production of Turkey increased from 10,272 million kwh ( 17.9 per cent) in 1990, to 35.180 million kwh (30.0 percent) in $1999 .{ }^{26}$

The main factor likely to affect Turkish and Russian policies will be possible mutual economic advantages and a foreign policy that will affect those areas of mutual benefit. For example, Russia's foreign policy on the Caucasus and Central Asia will immediately affect Turkish foreign policy. As for Turkey, the future of Turkish-Russian relations depends on Russia's importance to Turkey, both economically and politically, being realised by Turkish politicans and also explained to the Turkish public openly and clearly. The volume of investments Turkish businessmen have in Russia clearly shows the economic importance of Russia of Turkey. It is very important for Turkey not to enter into economic and political arrangements with Eurasian neighbours if such arrangements prejudice its relationship with the Russian Federation. Unfortunately, due to the low level contact between the Turkish and Russian governments, domestic political turmoil in turkey and the recent crisis and political uncertainty in Russia, Turkish-Russian relations will remain difficult for some time to come.

\subsection{Turkey-Turkic Republics}

The main factors affecting the relationship between Turkey and the Turkic republics of Central Asia are as follows.

i) Firstly, there is the question of payment. Some of the republics are potentially extremely wealthy. Turkmenistan has huge reserves of natural gas. Kazakhstan has considerable proven hydrocarbon reserves and Western oil companies are excited by the prospect of redeveloping the Azerbi energy sector. Uzbekisan, too, has large reserves of gas, in addition to other raw materals, such as gold. Most of this wealth remains underground and due to the lengthy lead times involved in exploration and pipeline construction schedules, it is likely to be some years before these republics acquire significant hard currency 
purchasing power. The situation contrasts with Russia, whose gas exports to Turkey provide the basis for a lucrative counter-trade relationship.

ii) Secondly, is the problem of logistics. In spite of the cultutral and linguistic similarities which exist between Turkey and her Turkic neighbours, Turkey does not have a common border with any of the Turkic republics (with the exception of the Autunomous Republic of Nakhichevan, which itself is geographically separate from Azerbaijan). This makes transport and other communications very difficult, all the more so as such routes have to pass through either Armenia or Iran to reach Turkey. Moreover, Turkey is located at the western end of the belt of new republics. Whilst this makes Turkey a plausible route for land transit links to Europe, it is not necessarily always the most attractive. Increasingly, the republics are finding that supply routes to the south, to reach seaports in Iran and Pakistan, are a cheaper and, sometimes, a more attractive option.

iii) The third important problem faced by Turkey in exploiting its new relationships to the east is the presence of other competitive regional powers. Not so much Iran, although Iran is likely to be an important link to the ports of the Persian Gulf but rather Russia. At present Russia has an advantage because of the legacy of the Turkic republics' infrastructural dependencyon her. Moreover, Russia and the southern republics remain economically integrated. This situation is likely to remain at least until the infrastructural diversification process takes place. The situation is made more delicate by the existence of political and demographic factors. All of the southern republics contain large Russian minorities.

The Russian population in Central Asia constitutes a potential threat to the region's stability. That is because the ethnic, cultural, religious and linguistic characteristics of the Russians are quite different. The Russian population constitutes $34 \%$ of the total population of Kazakhstan, $18 \%$ of the total population of Kirghizstan, $13 \%$ of the total population of Turkmenistan, $8 \%$ of total population of Uzbekistan, and $8 \%$ of the total population of Azerbaijan. ${ }^{27}$ In the northern parts of Kazakhstan the population of Russians is more than the native Kazakhs. That is why the capital of Kazakhstan has been changed from Almaty (in the south) to Astana in the north of the country. The aim of the Kazakh government is to counteract the influence of Russian population in the north. Taking into account that the Kazakh-Russian border is $3000 \mathrm{~km}$. long, it is obvious how serious the problem is. ${ }^{28}$

iv) Fourthly, Turkish policy toward the Turkic republics will need to be alert to these republics' sensitivities. In Turkey some Turks began to refer to themselves as the "big brother" to the Turks in Caucasus and Central Asia, 
perhaps unaware that the Russians from the outset of the Bolshevik period used to refer to themselves a the "big brother" to all other nationalities in the Soviet Union. Hence, that term is hated and redolent of the worst days of Russian domination; the Turks of the region are decidedly not looking to find a new "big brother". ${ }^{29}$ Kazakhstan, in particular, felt more uneasy than the other Turkic republics because almost $34 \%$ of its population is Russian. Kazakhs may be considered a minority in their own country when other ethnic groups are taken into account. Naturally, brotherhood with Turkey naturally means little to the Russian minority. Even the term "guide" as applied to the role of Turkey does not sit well, although nearly everyone can accept the term "model". Turkey will need to avoid any hint of latter day domination in either the political or the economic realm.

\section{The Effects of the Customs Union on the Trade Relations of Turkey with the Third States: as in the Case of ECO}

The effects of the EU Customs Union on Turkey's trade relations with third countries is significant with regard to the future of ECO. A relationship of association was set up in 1963 between Turkey and the EC by means of the Ankara Agreement. The additional Protocol which came into force on January 1, 1973 provided for the realisation of a Customs Union within 22 years and determined how such a union would be established. The Customs Union provided for in the Ankara Agreement and the Additional Protocol encompasses the mutual abolition of customs duties, charges having equivalent effect, quantitative restrictions and measures having equivalent effect on imports and exports and the adoption by Turkey of the Common Customs Tariff.

Just before the realisation of the Customs Union on January 1, 1996, Turkish goods were being protected by tariffs with ratios of $18 \%$ on EU goods and $23.7 \%$ on goods from third countries. With the entry into force of the Customs Union, those ratios fell to $0 \%$ and to $6-6.5 \%$, respectively. In other words, the Customs Union exposed the Turkish economy to serious competiton from EU and third countries. Its dynamic functions will be manifest in the medium term as a more efficient use of resources and a fall in the costs of production.

The likely effects of the Customs Union on trade relations between Turkey and ECO countries may be summarised as follows. A free trade area with ECO is maintained by means of the RCD. Since ECO is the successor of the RCD, the Ankara Agreement is equally appliable to ECO. Consultations on the application of regional co-operation for development will be made in the Council of Association which will decide on the necessary measures. The realisation of this goal in collaboration with the EU constitutes a legal basis for the establishment of a free trade area by Turkey in the region. If this process 
is initiated, the EU will not have any objections, because it is in need of the energy sources and raw materials of Central Asia.

The massive potential and resources in the ECO area will be influential in directing EU capital investments to the region. Moreover, ECO constitutes a large market for the EU with a population around 345 million. It will be benefical for both the EU and ECO if such a free trade area is formed with Turkey's co-operation even though it may be a project which can be realised only in the long run.

However, the significant point is that the development of trade relations between Turkey and ECO, and especially with the Turkic republics will not be at Turkey's sole discretion due to its obligation to comply with the Common Customs Tariff. In other words, Turkey can improve its relations with the Turkic republics of ECO only insofar as they are compatible with EU interests. This resriction derives from the fact that Turkey entered the process of Customs Union without first becoming a member state of the EU. A very important aspect of the Customs Union is that three important opportunities are denied to Turkey within the framework of the Ankara Agreement. Firstly, is unable to take part in the decision-making mechanism of the Community. Secondly, as an associate member, Turkey is excluded from the dispute resolution mechanism of the Community. Thirdly, Turkey is no part of the financial mechanism of the Community.

Turkey, through the Customs Union, is unable to participate in the decisionmaking processes of the EU. On the other hand, Turkey is under an obligation to complying with the common commercial policy of the EU. Because Turkey's relations with third countries will be shaped by the EU, this obligation may create important problems with regard to Turkey's ability to develop relations with third countries. Turkey is able to submit only its observations, without being allowed to influence the decisions. Turkey's interests in a cooperation such as ECO will be observed only insofar they are compatible with EU interests.

Turkey may consider such regional pacts as complimentary to its collaboration with the EU but, in line with its own interests, only if Turkey grows more powerful economically and politically.

Indeed, Turkey's close historical and cultural relations with the Turkic republics may later constitute an important possibility in the formation of closer cooperation between ECO and the EU. However, this is a situation which may gain significance depending on Turkey's efforts. Under these circumstances, the following questions are of importance 
- How and up to what extent will the Common Customs Tariff inhibit Turkey's attempts to find new markets outside the EU? Is it possible to formulate clearly how the technical mechanism can operate in this field?

- Can some serious shortcomings be expected in the fulfillment of obligations to both the EU and the ECO states? (The latter do not yet envisage integration).

- What kind of diversions can be expected in trade flows?

- Can Turkey make commitments incompatible with the Common Customs Tariff in her relations with third countries? In other words, can it make tariff reductions based on mutual commitments? Would it be difficult for Turkey to maintain commercial developments which are not compatible with EU policies in a world where trade is increased by means of multilateral trade agreements?

The results of three important researches about the effects of the Customs Union between Turkey and the EU on Turkey's trade relations with third countries give us some clues with regard to the future, even though it is difficult to express ideas covering the long run because the process of Customs Union is in its fourth year only. The first two of these researches which will be eplained briefly below examine the effects of the Customs Union on Turkish economy and on Turkey's trade relations with third countries while the third one examines the economic structures of ECO countries and its implications on trade relations among them.

i) According to the study of the World Bank on "Economic Implications for Turkey of a Customs Union with the European Union: A Quantitative Based Policy Analysis" (a study conducted before the Customs Union was realised), published in May 1996, Customs Union and its effects on Turkey's trade with third countries can be summarised as follows:

Under the Customs Union, Turkey must eliminate its tariffs and levies on imports of manufactured goods coming from the EU. Turkey must also apply the EU's Common External Tariff (CET) to third country imports. This will also involve a substantial reduction of tariffs against imports from the third countries because the the "most favored nation" (MFN) tariff of the EU is only about 7-8 per cent on average. Equally, though, application of the EU's CET means that Turkey must provide preferential access to its markets to all third countries to whom the EU grants preferential access, including:

- all the eastern European countries with whom the EU has association agreements;

- the countries in the Mediterranean that are subject to the EU's Mediterranean Policy;

- the African, Caribbean and Pacific countries that are part of the Lome convention; and

- GSP treatment for eligible countries. 
Turkey is expected to negotiate preferential trade agreements with all these countries by 2001 . On current data, Turkey's average tariff on non-agricultural imports will be less than 2 per cent compared with zero for imports from the EU and just over 3 per cent for third countries). ${ }^{30}$

Since Turkey is combining its tariff elimination on imports from the EU and tariff reductions on imports from third countries, she will become a rather open economy in non-agricultural sectors. This complementary tariff reduction should be cast in a good light since it reduces the trade diversion costs of the Customs Union, and results in additional gains from trade. Moreover, since the preferential access agreements are usually reciprocal. Turkish exporters may expect improved access to thosee markets. This suggests that improved access to third country markets results in gains to Turkey that are quantitatively the most important element in the Customs Union arrangements. 31

Movement toward a more open economy presents important challenges for Turkey. For example, how may trade and tax policies be used in Turkey so that significant unintended distortions are not introduced into the economy by the effects of the Customs Union. For example, the Customs Union will impose no restrictions on Turkey with respect to its tariffs on agricultural imports.

ii) The study of the Economic Development Foundation (IKV) on "The Impacts of the Customs Union on the Turkish Economy: An Econometric Analysis of the First 4 Years", published in early 2000, examines the short and long run commercial and fiscal impact of the Customs Union. The Customs Union will create far-reaching changes in the commercial and competition policies of Turkey. It should be emphasized that Turkey and the EU, may consolidate the success of the Customs Union by realising common interests and striving towards economic and institutional integration. The Customs Union did not appear to have caused trade diversion away from third countries. It is also claimed that no significant difficulties have resulted from the Customs Union over the last four years and that the effects of the Customs Union have not been too great. ${ }^{32}$

Although there is so far no evidence of trade diversion from third countries, the expansion of trade between Turkey and ECO countries - especially Turkic States - has been very slow in comparison with Turkey-EU trade (Table 1). The similarity of ECO economies may be the main reasonfor this, rather than the effects of the Customs Union on them. 


\section{Table 1: Turkey's Trade with Country Groups (US \$ m)}

\begin{tabular}{|c|c|c|c|c|c|c|c|c|}
\hline $\begin{array}{l}\text { Country } \\
\text { Groups }\end{array}$ & & 1994 & 1995 & 1996 & 1997 & 1998 & $\begin{array}{l}1999 \\
\text { (Jan.- } \\
\text { Nov.) }\end{array}$ & $\begin{array}{l}\% \text { of } \\
\text { Total } \\
\text { Trade } \\
99\end{array}$ \\
\hline \multicolumn{9}{|l|}{$\begin{array}{l}\text { A.OECD } \\
\text { Countries }\end{array}$} \\
\hline \multirow{2}{*}{ EU } & Export & 8.635 .3 & 11.070 .8 & 11.548 .6 & $12,247.8$ & $13,498.0$ & 12.756 .2 & 53.8 \\
\hline & Import & $10,915.3$ & $16,860.5$ & $23,138.1$ & $24,869.7$ & 24.074 .7 & $18,874.6$ & 52.6 \\
\hline \multirow{2}{*}{ EFTA } & Export & 276.9 & 293.3 & 335.9 & 414.3 & 356.7 & 327.7 & 1.4 \\
\hline & Import & 562.6 & 892.0 & $1,112.1$ & $1,287.2$ & $1,169.2$ & 802.1 & 2.2 \\
\hline \multirow{2}{*}{$\begin{array}{l}\text { Other OLCD } \\
\text { Countries }\end{array}$} & Export & 1.845 .7 & $1,925.0$ & 2.541 .9 & $2,921.1$ & $3,124.7$ & 3.045 .2 & 12.8 \\
\hline & Import & $3,852.9$ & $5,947.3$ & $6,841.1$ & $8,658.3$ & $8,228.0$ & $5,371.5$ & 15.0 \\
\hline \multirow{2}{*}{$\begin{array}{l}\text { B. Non- } \\
\text { OECD } \\
\text { Countries }\end{array}$} & Export & 7.348 .0 & $8,346.8$ & $8,798.0$ & 10.677 .9 & $9,994.6$ & $6,918.0$ & 29.2 \\
\hline & Import & $7,939.2$ & 12.009 .0 & $12,534.9$ & $13,743.5$ & $12,449.4$ & $10,428.5$ & 29.1 \\
\hline \multicolumn{9}{|l|}{$\begin{array}{l}\text { C. Selected } \\
\text { Country } \\
\text { Groups }\end{array}$} \\
\hline \multirow{2}{*}{ BSEC } & Export & $1,636.5$ & $2,417.2$ & $2,905.1$ & 3.831 .6 & $3,237.6$ & $1,896.4$ & 8.0 \\
\hline & Import & $2,167.2$ & $3,998.1$ & $3,867.1$ & $4,476.0$ & $4,331.6$ & $3,314.7$ & 9.2 \\
\hline \multirow{2}{*}{$\mathrm{ECO}$} & Export & 752.1 & 904.9 & $1,129.1$ & 1.237 .0 & $1,125.0$ & 733.9 & 3.1 \\
\hline & Import & 922.2 & $1,136.8$ & $1,196.8$ & $1,099.4$ & 947.8 & 835.4 & 2.3 \\
\hline \multirow{2}{*}{ D-8 } & Export & 675.0 & 755.9 & 905.7 & 874.8 & n.a. & n.a. & n.a. \\
\hline & Import & $1,099.1$ & $1,488.6$ & 1.597 .1 & $1,563.2$ & n.a. & & n.a. \\
\hline \multirow{2}{*}{ CIS } & Export & $1,412.2$ & 2.056 .9 & $2,665.4$ & $3,512.0$ & $2,666.5$ & $1,324.7$ & 5.6 \\
\hline & Import & 1.821 .5 & $3,314.7$ & $3,074.2$ & $3,615.1$ & $3,724.4$ & 2.884 .9 & 8.0 \\
\hline \multirow{2}{*}{$\begin{array}{l}\text { Turkish } \\
\text { Republics }\end{array}$} & Export & 429.6 & 543.0 & 747.2 & 858.4 & 835.0 & 481.3 & 14.9 \\
\hline & Import & 189.7 & 287.3 & 304.0 & 391.9 & 449.0 & 355.8 & 1.0 \\
\hline \multirow{2}{*}{$\begin{array}{c}\text { IOC } \\
\text { Countries }\end{array}$} & Export & $3,556.4$ & $3,872.2$ & $4,104.2$ & $4,209.6$ & 4.374 .9 & $3,524.2$ & 14.9 \\
\hline & Import & $3,566.5$ & $4,617.3$ & $5,566.9$ & 5.275 .8 & $4,210.6$ & $3,088.9$ & 8.6 \\
\hline \multirow{2}{*}{$\begin{array}{c}\text { Turkish } \\
\text { Free Zones }\end{array}$} & Export & - & - & - & - & $751.4^{*}$ & 656.6 & 2.8 \\
\hline & Import & - & - & - & - & $389.1^{\circ}$ & 416.5 & 1.2 \\
\hline \multirow[t]{2}{*}{ Total } & Export & $18,105.9$ & 21.637 .0 & $23,224.5$ & 26.261 .1 & $26,974.0$ & 23.703 .7 & 100.0 \\
\hline & Import & $23,270.0$ & $35,709.0$ & 43.626 .6 & 48.558 .7 & $45,921.4$ & $35,893.2$ & 100.0 \\
\hline
\end{tabular}

Source: T.R. State Planning Organization

* January-November 1998. 
iii) According to the article "Central Asia Turns South?: Trade Relations in Transition", by Professor Richard Pomfret by Adelaide University, Australia, since becoming independent, trade between the five Central Asian republics and their Islamic neighbours has grown from a very low base. The volume of trade between the five and Turkey, Iran and Pakistan still remains disappointing. In the Soviet era, the trade of the five Central Asian republics was overwhelmingly carried on within the Soviet Union, and economic links to the south were negligible.

The collapse of the Soviet Union transformed the geopolitics of Central Asia. That new relationship with Turkey, Iran and Pakistan seemed to take off in 1992, when the five Central Asian republics (plus Azerbaijan and Afghanistan) joined the ECO. It was hoped that ECO would serve as a catalyst for trade. But while Central Asian trade links with the south have increased, they remain less significant than links to countries outside the region.

This trade has been slow to develop because the physical infrastructure of the region does not favour the rapid expansion of regional trade. Long-distance highways are lacking. Existing roads are poor, and railways underdeveloped. These transportation problems make it difficult to move goods. Moreover, the former Soviet republics' main rail, road and pipeline links go north to Russia, or west through the Caucasus. There are no rail or pipeline links to the south, and only poor road and waterway links. ${ }^{33}$

Inadequate transport is only part of the problem. The main reason why trade has been so slow to develop is the similar nature of the national economies of the Central Asian republics and their ECO partners.

ECO members produce a mostly limited range of primary products such as cotton, minerals, oil and gas. This narrow export base means ECO economies are not complementary to one other, but must compete with each other. That is the main reason why intra-ECO trade has not increased (Table 2). ${ }^{34}$

For many of these countries, their natural export markets lie outside the region - in East Asia, Western Europe, or North America rather than within the region. Natural suppliers of manufactured goods also lie outside the region. Turkey, Pakistan and Iran have diversified manufacturing sectors that can provide some consumer goods to Central Asia, but even here the major global suppliers are outside the region (Table 3 ).

Despite cultural and historical links there is little logic to strengthening their relationship with the south. 
Table 2: Economic Co-operation Organisation (ECO)

\begin{tabular}{|c|c|c|c|c|c|c|c|c|c|c|c|}
\hline \multirow{2}{*}{\multicolumn{2}{|c|}{$\begin{array}{c}\text { MEMBER } \\
\text { STATES }\end{array}$}} & \multicolumn{2}{|c|}{ Afghanistan } & \multicolumn{2}{|c|}{ Averbaijan } & \multicolumn{2}{|c|}{ Irun } & \multicolumn{2}{|c|}{ Karykhstan } & \multicolumn{2}{|c|}{ Korgazostan } \\
\hline & & $\begin{array}{l}\text { I } \\
\text { II } \\
\text { P }\end{array}$ & $\begin{array}{l}\text { v } \\
\mathbf{p} \\
\mathbf{p}\end{array}$ & $\begin{array}{l}\text { I } \\
\text { A }\end{array}$ & $\begin{array}{l}\mathbf{k} \\
\mathbf{x} \\
\mathbf{p}\end{array}$ & $\begin{array}{l}1 \\
31 \\
1\end{array}$ & N & $\begin{array}{l}1 \\
\text { y } \\
\mathbf{p}\end{array}$ & $\begin{array}{l}\mathbf{k} \\
\stackrel{p}{p}\end{array}$ & $\begin{array}{l}\text { t } \\
\text { it } \\
\text { P }\end{array}$ & is \\
\hline \multirow{5}{*}{ Arghenistian } & (9094 & 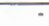 & - & n.a & n, & 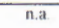 & 11. A & ก. & n... & n.t. & II. \\
\hline & 1995 & - & - & 0 & I & 0 & $"$ & $1)$ & 0 & 1) & 3 \\
\hline & $19 \%$ & - & . & 1 & $t$ & 11 & (b) & 6 & 0 & 7 & 0 \\
\hline & 1997 & - & - & 11.: & In.a. & n.u. & 1.. & 18. A & it:a & 1.i. & ถ1.a \\
\hline & $19 \% 8$ & - & - & n.a. & al,a. & nii. & 11.91 & na. & n.A & n.a. & B.a. \\
\hline \multirow{5}{*}{ Azerhsij,jnn } & 1994 & $1 ?$ & 1.1 & $=$ & - & 66.8 & 257,3 & 514 & 16.5 & 24 & 2.2 \\
\hline & 1995 & 11.1 & p.t & - & . & *I!.3 & $|x 6|$. & 17.6 & 20.5 & 1.8 & 0.8 \\
\hline & lew, & 0.1 & 11 & - & . & andu & 2261 & 193 & 15.4 & 3.5 & 1.1 \\
\hline & $19 \% 7$ & 0.3 & 0.2 & . & - & $+4 x$ & 1897 & 29.6 & 9.0 & 1.4 & 1.8 \\
\hline & $14 \%$ & 0 & 12 & - & . & +2.6 & +4.5 & H.t & 111.6 & 1.2 & +.4 \\
\hline \multirow{5}{*}{ Iran } & 1994 & 9.0 & 30.3 & .3132 .2 & 20130 & 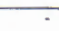 & - & 31) 2 & 33.4 & 58 & M. \\
\hline & Iy9s & 2.5 & $2+.1$ & 2096 & 1607 & - & - & 735 & $\$ 6.2$ & 7.3 & 34.7 \\
\hline & $10 \times x_{1}$ & 6.2 & 23.9 & $251 \times$ & $2(x): 51$ & . & - & 112.1 & 15.1 & 27.2 & 32.3 \\
\hline & 1997 & 3.3 & 14.5 & 119.2 & 21.3 .4 & . & - & 9) 8 & 32.8 & 13.2 & 210 \\
\hline & rews & 1). 1 & 19 & $3 \times .8$ & 120.3 & - & - & *7.2 & 245 & 14.2 & 12.2 \\
\hline \multirow{5}{*}{ Kuakhstun } & T1944 & 83 & $T .8$ & 11.7 & $4 \sqrt{3} 3$ & 105 & 118 & - & - & (14.1) & 509 \\
\hline & 1945 & 0.1 & 2.9 & 25.2 & 23.1 & 13.8 & fi) 2 & - & . & 31.4 & 74.9 \\
\hline & 1996 & " & 5.7 & 22.6 & 9.6 & 6.1 & 62.5 & - & - & 910 & 111.6 \\
\hline & 19197 & " & 8.6 & 10.4 & 27.2 & 8.9 & 83.3 & . & - & 6) 5 & 66,2 \\
\hline & $190 x$ & 1) & 7.5 & 9.1 & 24.8 & 9.6 & $(x, y)$ & . & - & 48.4 & 02.8 \\
\hline \multirow{5}{*}{ Kirgyestan } & पि94 & 7 & $\overline{211}$ & 0.6 & 16 & 87 & 42 & $5 \times 3$ & 45.2 & - & ? \\
\hline & 1995 & 30 & 311 & 3,3 & 2.1 & 2.3 & +1 & 112.5 & $6(x) x$ & - & - \\
\hline & $14 \%$ & 0 & 6.5 & 1.t & 32 & 3.4 & 63 & 130.5 & $1: 2.5$ & - & - \\
\hline & 19יר & v & 4.1 & 2.5 & 28 & 57 & 6.2 & 69.6 & K7. 1 & - & . \\
\hline & f & ") & 2.9 & 72 & 2.6 & 77 & $s t$ & 75.3 & 85.5 & - & - \\
\hline \multirow{5}{*}{ Pakistan } & 1904 & 114 & 32.7 & 0 & (1) 4 & $64 t$ & 76.7 & 2.2 & 7.5 & 0.0113 & 101 \\
\hline & 1905 & 22.4 & 13.2 & 0.1 & $x x$ & 182.6 & 118.1 & In. & 13.5 & 0.1001 & 0.9 \\
\hline & $w \%$ & 326 & $15 ?$ & 0.2 & 107 & 2k5.9 & 15.9 & t.t. & 10.2 & D. Hor & 3.8 \\
\hline & 19097 & 27.6 & 313 & 11.5 & It. & 157.9 & 235 & 10.6 & 19,3 & 0.145 & 79 \\
\hline & $\{904$ & 37.1 & $\$ 8.5$ & 0.6 & 1.9 & $7 \times 0.1$ & 11.3 & 0.3 & 12.6 & $0.1 \times 05$ & 4.1 \\
\hline \multirow{5}{*}{ Tujikistun } & 1964 & 1.3 & $\overline{10.8}$ & 0.2 & 12 & 0.1 & T.t. & $32 \%$ & 10.1 & 1.1 & 19 \\
\hline & 1945 & 13 & 113 & 1.2 & 0.9 & 0.7 & 0.7 & 26.6 & 7.0 & 2.7 & 2.7 \\
\hline & Iינונ, & 2.3 & 1.5 & 0.1 & 2.6 & (10). 5 & 1.7 & $52+t$ & $2+3$ & 7.2 & $10, .5$ \\
\hline & $19 \times 97$ & 107 & 11.8 & 3.2 & 0.1 & 1201 & 1.5 & +2.0 & 1010 & $5+$ & 30 \\
\hline & 1408 & 0.5 & 0.6 & 18 & 18.4 & 113 & 136 & 31.9 & 10.0 & 5.3 & 58 \\
\hline \multirow{5}{*}{ Turkes } & Toyt & (1) & 1,6 & $x \cdot$ & 132.1 & 6924 & $2+4,8$ & 32.3 & 131.8 & +3 & 17.0 \\
\hline & 1995 & 0.1 & 0.5 & $21 . K$ & 161.4 & $6 \times 9.5$ & $26 x+$ & 86,6 & $150 . \mathrm{K}$ & 5.5 & 38.2 \\
\hline & IYK, & 0.2 & 2.1 & 302 & $2.20 \%$ & $80 \times 3.3$ & 297.5 & tom 6 & {$[6+1\}$} & 5.9 & 47.1 \\
\hline & 1947 & a 7 & 63 & $5 \times 3$ & 119.7 & $\cos 6.1$ & 307.0 & 165.3 & 2106 & 7.6 & t4. $f$ \\
\hline & Iyek & 1.4 & 21.7 & +4y & 326.3 & +32.8 & 104.6 & 2537 & $21+.11$ & 7.4 & $\$ 17$ \\
\hline \multirow{5}{*}{ Turkmenistun } & Tणभ & $2+2$ & 21.7 & 72.1 & 192.1 & 71.1 & 217 & $\sqrt{2.5}$ & 28.3 .2 & 17.9 & 124 \\
\hline & 1915 & 6.6 & 0.1 & 73.2 & 19.9 & 36.3 & 114 & 34 & $127+$ & 3.8 & 6.) \\
\hline & Iיא, & 4.1 & 12.9 & 3.9 & 11.2 & 15.2 & Ifiy & 22.2 & $5+.1$ & 1.1 & 0.8 \\
\hline & 1907 & 2.0 & 211.9 & 21.5 & 29.2 & 38.7 & 123.5 & $\$ 6.9$ & 30.8 & 2.3 & $13+$ \\
\hline & 1998 & 18.4 & 20.4 & 15.2 & 42.6 & $1 \times 1$ & $1+43$ & 28.6 & 25.2 & 2.1 & 5.8 \\
\hline \multirow{5}{*}{ Uxhekiantan } & 1904 & 0.4 & 4.2 & 0.6 & 12 & 10.5 & 35 & 148.5 & 2.40 & 250 & 573 \\
\hline & 1945 & 11 & 17.2 & 1.2 & 3.9 & $2 . y$ & 1.7 & 217.9 & $23 \times 1$ & $3+.1$ & $6 \times 3$ \\
\hline & 1996, & 8.8 & 20.2 & +.3 & 3.5 & 516 & 21.8 & $222.3^{3}$ & $1: 90$ & 17,0 & 83.8 \\
\hline & 1997 & 2.7 & 17.2 & 20.4 & 31 & 37.2 & 11.13 & 196,3 & 1977 & 19.2 & 54.4 \\
\hline & loys & 6.6 & II.K & 3.0 & 2.2 & (0.0) & 31.2 & 162.6 & 122.0 & 202 & 31,2 \\
\hline
\end{tabular}

Source: T. R. Undersecretariat of Foreign Trade 


\section{Intra-Regional Trade (USS in mio)}

\begin{tabular}{|c|c|c|c|c|c|c|c|c|c|c|c|c|c|}
\hline \multicolumn{2}{|c|}{ Pakistan } & \multicolumn{2}{|c|}{ Tajikintan } & \multicolumn{2}{|c|}{ Turkey } & \multicolumn{2}{|c|}{ Turkmenistan } & \multicolumn{2}{|c|}{ Uzhekistun } & \multicolumn{2}{|c|}{ Tatal ECO } & \multicolumn{2}{|c|}{$\begin{array}{c}\text { "\% iff Total } \\
\text { Trade }\end{array}$} \\
\hline 1 & F: & 1 & v. & 1 & f: & : & *. & $1^{*}$ & $\boldsymbol{E}$ & 1 & E & 1 & r: \\
\hline II & $x$ & s1 & $\mathrm{x}$ & i1 & $x$ & is & $i$ & v & $x$ & $\$ 1$ & $\dot{x}$ & i & $x$ \\
\hline & & & P & $\boldsymbol{\gamma}$ & p & P & $r$ & $p$ & $\mathbf{p}$ & $P$ & $\mathbf{P}$ & $\mathbf{p}$ & I' \\
\hline 4. & in il & 11.3. & $11 \%$ & 11.:1 & n.a & 11.2. & 17, a & n...1 & nit. & h.a. & 11. 4 & M.a. & 11.3. \\
\hline 22 & 14 & 1) & 4) & c: & 11 & 111 & a & 1.a. & ia & $3 k$ & 24 & $10,6 \mathrm{r}$ & $1+.5$ \\
\hline 14 & 25 & 2 & 2 & 8 & 0 & 11 & + & na. & 11.a. & 52 & 32 & 112.5 & 25.6 \\
\hline ก.н. & 11.4 & n.a. & n.a. & n.a. & n.ak & ก. ต. & n.a. & it.a. & n.a. & ก.A. & na & n.a. & 11.a \\
\hline n... & n.a. & Il.a & n.a. & n.a & n.. & i.a. & $\mathbf{n} ; \mathbf{a}$ & ถ⿱亠乂. . & nal. & in.a. & n.a. & n,a & ก.4. \\
\hline 01 & 71 & 18.2 & 1.1 & 760 & 16.5 & 1956 & 17.1 & 2.6 & 2.7 & 396.8 & $31+5$ & 510 & 18.2 \\
\hline 0.5 & (1) 1 & 0.1 & 3.7 & $1 \notin 0.5$ & 26.4 & 31.4 & 70.6 & 7.7 & 39 & $3(x), 0$ & 312.1 & H.9 & $\$ 9.11$ \\
\hline 1).4) & 11113 & 11.4 & 17 & 216.3 & 39.0 & 14.7 & $3+3$ & 7.2 & 56 & $328+$ & 123.3 & $3+2$ & 51.2 \\
\hline 0,3 & 112 & 0.1 & 34 & 1797 & $\$ 1.3$ & 253 & 85 & 5.5 & +3 & 2910 & $258+$ & 36.6 & 33.1 \\
\hline 11.4 & 0102 & 0.2 & 1.0 & 2211.1 & $135 x$ & 26.4 & 13.3 & 2.8 & 2.11 & 338.1 & $21+11$ & 31.4 & 353 \\
\hline $53+$ & 1717 & 1.2 & 79 & 27,38 & $k_{1}+k$ & 33.5 & 6,5 & 77 & 26.8 & $811 . x$ & $14+5$ & 6.9 & 74 \\
\hline $16 \$ 1$ & 1540 & $n, 3$ & 11.4 & $2+41$ & $7(1)=9$ & 17.6 & 40.5 & 3.9 & 69.9 & 719.9 & 1312 & 5.8 & 71 \\
\hline 53.8 & 1772 & 1.7 & 21.7 & $2 x+1.1$ & $71 k_{i} .3$ & $x$ & 125.1 & $2+2$ & 124.6 & 770.11 & 1156 & 5.1 & 6.5 \\
\hline 227 & 1775 & 33 & $2 \times 1$ & $2 \times 4.1$ & $5+54$ & 5.5 & $6+6.2$ & 176 & 114.2 & 573.7 & 1284 & so & 7.0 \\
\hline 27.3 & 934 & 4.1 & 25.8 & 271.9 & 4.37 .7 & 5.5 & $1<12.3$ & 27.9 & 53.7 & 476.9 & $x 76.5$ & 3.3 & 7.3 \\
\hline 49 & 19) & 17.9 & 9.5 & 872 & की 1 & 2776 & 25,3 & 276,6 & 117.2 & $74 \times 1 \times$ & 325.8 & 150 & 9.2 \\
\hline 1.4 & 32 & 12.1 & $+11+$ & 123.5 & 711.4 & $2+13$ & +75 & 269.5 & 1531 & 717.9 & 16. 1.7 & $6+$ & 7.9 \\
\hline (1) 2 & 122 & 17.5 & 607 & 151.2 & 51.7 & 176.2 & $3 \times 8$ & $x \cup 3$ & 201.8 & $55+0$ & 5546 & $7 x$ & 83 \\
\hline 03 & $2 \mathrm{H}$ & 63 & 550 & 1770 & 102.2 & +6. 1 & +4.8 & 60,0 & $1+4.4$ & $3 \times 7.5$ & 539.5 & 50 & 7.5 \\
\hline 0.5 & 23 & 3.9 & +2.2 & $2018 .+$ & 4.3 & 12.7 & 12.3 & $\% 3$ & 119.2 & $38 K .4$ & 4373 & 5.1 & 7.4 \\
\hline 1) & 0.2 & 1.1 & 3.11 & 150 & (3) & 10.4 & 7.4 & $6,3.7$ & $\$ 3.6$ & 1498 & 157.1 & 17.3 & 46.2 \\
\hline 3.0 & 0.6 & $+x$ & 83 & 36.3 & 3.2 & 18.6 & 2.2 & 8X.9 & 711 & 2747 & [(6) 3 & 52.6 & 39.2 \\
\hline+1 & 10.t & 6.3 & $x .3$ & 176 & 5.3 & 13.6 & 3.2 & 131.5 & 115.6, & 347.4 & 261.5 & +11.5 & 517 \\
\hline 5.7 & 1.1 & 111.13 & 12.7 & +7.3 & 80 & 15.5 & 2.6 & $12 \times, 6$ & 101.5 & 280109 & 226.1 & 39.6 & 37.4 \\
\hline 1.5 & 0.5 & (19.1) & 8.3 & $37 . t$ & 7.4 & $x .2$ & 1.2 & 1222 & 38.5 & 2695 & 152.3 & 32.17 & 29.7 \\
\hline- & - & 131 & 1.6 & 966 & 1111 & 0.1 & 48 & $\$ 1$ & 22.9 & $2 \times 14$ & $26+5$ & 27 & $3:$ \\
\hline - & - & 1305 & 60 & 79.0 & x.7. & (1.t & 11 & 0.3 & +3.4 & 285.1 & 208.8 & $2 . t$ & 3.5 \\
\hline . & - & $0 .+10$ & 4.5 & 9.1 & 6.26 & 2.2 & 6.6 & 1.2 & $3 \times .11$ & 348.1 & 1675 & 3.3 & 20 \\
\hline - & - & 0.30 & 10.0 & $\$ 2.1$ & 69.9 & 0.5 & 7.2 & 2.3 & 33.1 & 231.7 & 213.6 & 2.3 & 2.5 \\
\hline$=$ & - & 1.211 & +.2 & $1,32.6$ & 3513 & 118 & 2.1 & $6+6$ & 11.4 & 315.2 & 131.6 & 33 & 1.7 \\
\hline$\sqrt{18}$ & n & $=$ & - & 167 & 76 & 301 & 1.8 & 83,? & 22.7 & 176.6 & 46.5 & 32.3 & 9.5 \\
\hline $3 x$ & 0 & . & . & 34 & 8.1 & 57.4 & 2.2 & $231+$ & 132.11 & 347.7 & 1579 & +2.9 & 7.6 \\
\hline 6.0 & $1+$ & - & - & 5.3 & 1.9) & 26.7 & 8.5 & $10 \times 4$ & $1 \times 1 \times .7$ & 300.0 & $2+31$ & +63 & 316 \\
\hline 1.1 & 3.3 & - & - & 5.13 & 82 & 24.7 & 149.3 & 201.6 & 172.5 & 3611.7 & 219.7 & $4 k .1$ & $2 \times 0$ \\
\hline 0.2 & 0.7 & - & . & 3.9 & 0.4 & 31.3 & $\times 7$ & 227.2 & 125.6 & 333.4 & 165.4 & 46.) & 27.7 \\
\hline 36,8 & 56.5 & 29 & 14.6 & $\cdot$ & - & 656 & 84.2 & 786 & $6+.5$ & 022.2 & 752.1 & +0 & 9.2 \\
\hline 1536 & 'xily & 6.3 & 0.1 & - & - & 111.8 & 56.3 & 61.5 & 1.385 & 11.37 & "ग110 & 3.2 & +.2 \\
\hline K3.5 & 77.9 & 2.8 & t. 4 & . & - & $116 \times 3$ & $6: 7$ & 5K. I & 23016 & 1197 & 1129 & 2.7 & +.9 \\
\hline 570 & 58.2 & 3.4 & 7.2 & - & - & 73,6 & 117.5 & 94.8 & 2106 & $|1| j 7$ & $12 k 7$ & 2.3 & 4. 9 \\
\hline 56.6 & 6.55 & 7.9 & 4.6 & - & - & $\$ 2.3$ & 95.8 & 05.7 & 156.2 & 947,6 & 1125 & 2.1 & 4.2 \\
\hline 1116 & (1)(114) & $2+19$ & 19.6 & $2+6.7$ & का ? & $=$ & - & 145 & $1+44$ & 5326 & 771.1 & 36,3 & $\overline{36,1)}$ \\
\hline $1 . x$ & +11.9 & 1.\% & 5.9 & 1600.3 & 149.6 & - & - & 28.5 & 213 & 343.8 & +22.4 & 25,2 & 22.9 \\
\hline 111.t & 12.7 & 2.115 & 10,015 & 13013 & 74.7 & - & - & 5.5 & 3.4 & 2458 & 2III. & 187 & $11 . \%$ \\
\hline 1.5 & $1,1 / 4$ & 8.7 & 24.7 & 153.8 & S19.4 & - & - & 87.9 & 511 & +103.9 & 304.4 & $32 . K$ & +10 5 \\
\hline 0.5 & 2.1 & 7.1 & 27.3 & $1+9,0$ & 112.5 & - & - & 62.11 & 7.1 & 282.9 & $3 \times 7.3$ & 28.4 & 6.5 .2 \\
\hline 12 & (3) & 2920 & 160.7 & 675 & 42.4 & $14+2$ & $17+3$ & $\overline{ }$ & 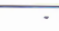 & $6 \times 1.7$ & 791.6 & 26.1 & 26.11 \\
\hline ข. 2 & 21 & 73.19 & 156.1 & H5.6 & [Iin 7 & 96,7 & 1519.4 & . & - & 523.8 & 747.8 & 18.1 & 219.1 \\
\hline 78.3 & 8.2 & 22.5 & 67.9 & $35 \% .9$ & +1.1 & 16.6 & 174.1 & - & - & $7+10$ & $\$ 43.5$ & 15.7 & $11 x$ \\
\hline 12.6 & $9 x$ & 603.5 & $1+6,4$ & 297.7 & 21,0 & 246 & $92 . K$ & - & - & $6+7.2$ & s1i.t & H.4 & 11.7 \\
\hline 38 & $2 . x$ & 15.8 & 122.2 & 19811 & +5.3 & 6.6 & 155.17 & - & - & 4358 & $5+3.7$ & 133 & 15.4 \\
\hline
\end{tabular}




\section{Table 3: Commodity Composition of Foreign Trade of ECO Member Countries (1998)}

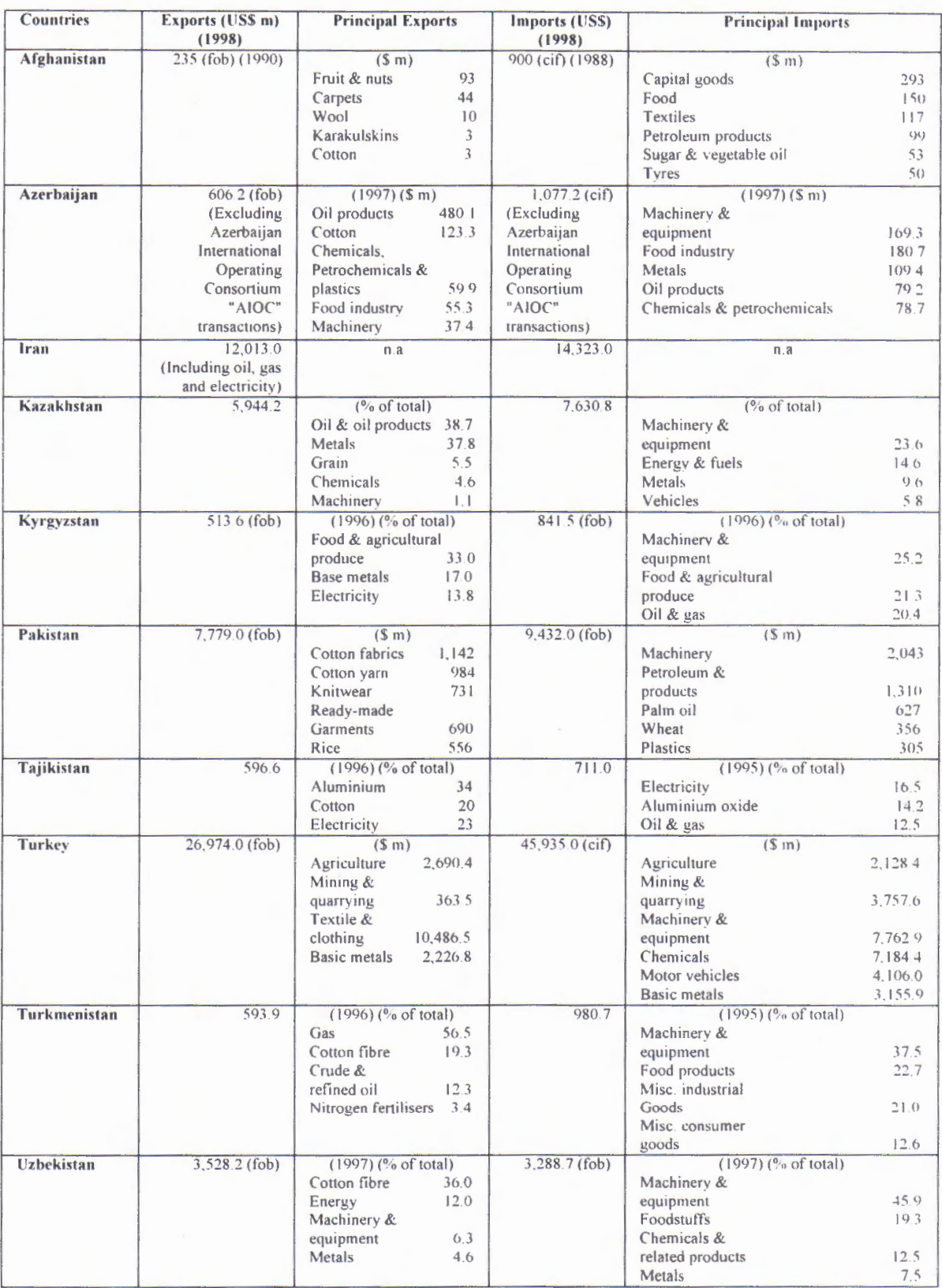




\subsection{Can Turkey be a "bridge" between the EU and the ECO?}

A common prejudice is that Turkey's close relations with the EU and its cultural ties with the Turkish states provide it with a special status within ECO and that. Turkey can act as a "bridge" between the EU and these countries ${ }^{35}$ With the opening of the East, two important areas in the zone of Turkish influence has now become accessible: the Caucasus and Central Asia. Turkey has an important role in this area but it is by no means a hegemonic one. Turkey is a European country geographically close to the Caucasus and Central Asia with historical and cultural ties there. However, Prof. Lorca says, "bridge theory" was used during the negotiations for Spain's entrance into the EU (then the European Community). Experience has shown that Europe does not need Spain for dealing with Latin America, though it cannot be denied that there are some advantages in using Spain as a catalyst. For example, Spain has become an unqualified defender of Latin American interests by taking on the role of its defense lawyer in Brussels. ${ }^{36}$

\subsection{Transport Roads of Oil and Natural Gas from the Caspian Basen to the World markets via Turkey}

At the Summit of the Organisation for Security and Co-operation (OSCE) in Istanbul on 18-19 November 1999, the governments of Turkey, Azerbaijan and Georgia signed an agreement on the construction of an oil pipeline from Baku, the Azeri capital, to the Turkish Mediterranean port of Ceyhan. In signing the Istanbul Protocol, the leaders of these three countries pledged themselves to the realisation of a pipeline from Baku to Ceyhan, carrying one million barrels per day and intended to bring oil produced in Azerbaijan, Kazakhstan and possibly elsewhere around the Caspian Basin to international markets. Turkey has agreed to underwrite cost overruns on its part of the $\$ 2.5 \mathrm{bn}$ pipeline. The same three governments and Turkmenistan signed an agreement on a $\$ 2.5$ bn $\$ 3$ bn pipeline to deliver gas across the Caspian Sea from Turkmenistan into Turkey. ${ }^{37}$ US President Bill Clinton also participated in the signing ceremonies of both projects. President Clinton's witnessing of the two agreements was a symbolic gesture demonstrating that the United States is commited to supporting both projects. However, after signing both agreements to remove barriers to an east-west energy corridor, Russia expressed opposition to the projects. "It is against Russian interests" said the Russian Foreign Ministry. ${ }^{38}$

The gas pipeline is scheduled to become operational in 2002 and the oil pipeline in 2004. ${ }^{39}$ The gas line will run from Turkmenistan beneath the Caspian Sea through Azerbaijan and Georgia to Turkey, which would ship much of the gas on to Europe. The oil pipeline will pump Caspian crude from Azerbaijan through Georgia to the port of Ceyhan, bypassing the Black Sea and the congested Bosporus and Dardanelles. The two pipelines make up what the 
Clinton administration calls the East-West Caspian Energy Corridor, which threads between Russia on the north and Iran on the south. However, due to the difficult commercial and political negotiaitons that lie ahead, both of these pipelines seem far from coming to fruition.

\section{a) The Blue Stream Project}

In addition to the pipeline projects signed at the OSCE Summit in Istanbul, there is another gas pipeline project currently under construction, from Russia to Turkey.

This project, known as Blue Stream, aims at one third of the new $\$ 1.5$ billion pipeline to running along the bed of the Black Sea. The target date for completion is in 2005. The 1,200 kilometer ( 750 mile) pipeline is intended to carry milions of cubic meters of gas to heat homes and run factories in Turkey. Moreover, the completion of the pipeline, will see Russia able to export natural gas to third countries through Turkey. The Russian government estimates that the pipeline will generate between $\$ 4.5$ and $\$ 7$ billion in government revenue over the life of the project, depending on natural gas prices, in the years to come..$^{40}$

The characteristics of the Blue Stream project and its significance for Turkey: ${ }^{41}$

i) Turkey's supply of natural gas is not secure. The only natural gas pipeline from Russia comes through the Ukraine, Romania and Bulgaria. As these countries give priority to their own needs, they are likely to vary, whenever they like, the amount of natural gas coming to Turkey. This has happened from time to time in the past, leaving large cities such as Istanbul facing serious energy problems. To meet the increasing needs of Turkey, this supply is supplemented by liquified natural gas, which is brought from Egypt and Algeria by tanker. However, the problems faced in the processing gigantic tankers, especially in winter, often causes delays and the natural gas industry is suffering losses as a result. Blue Stream hopes to eliminate these problems by pumping gas directly from Russia to Turkey..

ii) Russia regularly provided some western countries with natural gas even during the Cold War. Turkey, too, has been buying natural gas from Russia for almost ten years. Under these circumstances, the Blue Stream project will provide Turkey with four advantages: Firstly, the fact that Russia possesses $37 \%$ of the identified natural gas reserves of the world should enable Turkey to enjoy a reliable source of supply in the long run. Secondly, Russia promises to sell Turkey natural gas at below world market prices. Thirdly, the fact that the gas will come directly from Russia eliminates the 
risk of interruptions by third states. Finally, Russia has undertaken to meet the construction costs of that part of the project which lies between Russia and Samsun on the Turkish Black Sea coast.

iii) The responsibilities assumed by Turkey and Russia in relation to the project may be summarised as follows. As Russia undertakes the construction of the part of the pipeline between Russia and Samsun, Turkey takes no risk at this stage. Turkey is obliged to buy the natural gas only when it arrives at Samsun. Turkey's responsibility is to construct the section of the pipleline between Samsun and Ankara. Under the terms of the deal, Turkey must complete the construction of the Samsun-Ankara section by 2001 . Otherwise, it will have to pay Russia $\$ 1$ million for each day of the delay.

iv) Some have criticised Blue Stream for making Turkey dependent on a single country for its supply of natural gas. To answer this criticism, Turkey signed a natural gas pipeline agreement with Iran in 1997. Iran has already completed its part of the pipeline but Turkey has suffered delays in constructing its section of the work. The Turkish Energy Ministry has asked Iran for the constract to be extended. However, there is a political problem with the Iranian pipeline, namely that the pipeline may bring natural gas not only from Iran but also from Turkmenistan. This outcome would allow Turkey to diversity its sources of energy and reduce her dependency on Russian gas. However, some Turkish officals welcome the delay because the Iranians were regarded as friends of the former Erbakan government. Furthermore, it is well known that the US has not adopted an enthusiastic approach towards this project, because of the regime in Iran.

v) Another important point concerning the Blue Stream project is that the US and Turkmenistan oppose the project while Turkey and Russia hope to realise it. The US does not want Russia to play an important role in energy resources such as natural gas and oil. Nor does it want Russia and Turkey to establish closer relations by co-operating in the transportation of energy resources to world markets. Turkmenistan considers the project incompatible with its interests because it has concerns that the realisation of the project will diminish the possibility of selling its natural gas directly to Turkey. This project will create the possibility of selling the gas through Russia and Iran, and thus make it difficult to finance the construction of a pipeline conveying gas directly to Turkey. Turkmenistan is concerned that it will have to sell its gas to Russia and Iran at low prices. These countries will then have the opportunity to re-export Turkmenistan gas to Turkey and third counries at higher prices. 


\section{b) The Natural Gas Deal with Iran}

On 8 July 1999, a coaltion government was formed in Turkey by the religiously orientated welfare Party (Refah Partisi) led by Necmettin Erbakan, and the Conservative Party (Doğru Yol Partisi) led by Tansu Çiller. Erbakan had achieved his goals. He was Prime Minister, and, for the first time in the Republic's history, a party uncommitted to the traditions of Atatürk had become the leading power in government. The Turkish military, in particular, refused tolerate the abolition of the Kemalist foundations of the Turkish Republic and, one year later, forced Erbakan to resign. One of the more important acts of the government during its period in office was the agreement on the natural gas with Iran.

The agreement caused growing concern in the West, especially in the USA, about the political course of the new Turkish government. Washington's irritation was all too apparent, as the American president had signed a law just a few days earlier threatening to impose sanctions on all foreign firms investing more than $\$ 40$ million in the oil and gas sectors of Iran and Libya. Erbakan signed the agreement in Teheran on long-term supplies of natural gas through a pipeline to be built from Tabriz to Ankara with a financial volume of $\$ 20$ billion per annum. ${ }^{42}$

The project had already been promoted for over a year by former Prime Minister Çiller, and the agreement had been awaiting final signature for months. Erbakan's main contribution appears to have been his deletion of those clauses in the agreement which envisaged Turkish involvement in the financing of the part of the pipeline to be constructed by Iran. Consequently, the new American law had not been violated. Neverthless, there was a fierce reaction in Washington, though it was much more restrained than that of many Congress members and the US media.

There are real economic interests, however, which support the development of a cordial relationship between Turkey and Iran. The diversification of Turkish energy supply plays a significant role but it is by no means the most important. Turkey urgently needs additional energy imports to make sure that its needs are met into the future out in the medium term. Turkey will be unable to meet its rapidly increasing energy requirements over the next 15 to 20 years through its own resources. The current dependence on Russia in the gas sector is cause for concern and efforts are being made to reduce that dependence. In addition to those with Iran, supply agreements are also planned with Algeria, Nigeria, Qatar, and Turkmenistan. ${ }^{43}$ 


\section{Concluding Remarks}

ECO has the potential to change the economic and potential face of the Central Asia and the Caucasus. It is a organisation of developing countries struggling to cope with serious economic and political problems and difficult historical legacies. except the founding members of the ECO the others members, in other words seven of ten members are still in a transition process from socialist economy to a market economy and lack developed private sectors. This deficiency hinders market development and limits the scope for efficiency in resource allocation. Even the founding members Pakistan, Iran, and Turkey have their problems. Turkey, too, has serious political and economic problems, which it must face without the benefit of EU membership, though its Customs Union with the EU may begin to change that. Concerning the political problems within the ECO, the civilwar in Afghanistan and the Nagorno-Karabakh conflict between Azerbaijan and Armenia can be given as an example.

The pattern of economic development suggested to Central Asian republics and Azerbaijan is primarily based on the principle of exploitation of natural resources, generally in partnership with goreign companies. There has been much discussion concerning future possible routes for new oil and gas pipelines across Central Asia and the Transcaucasus from the Turkic republics. Turkey, Russia and Iran have been competingto secure the passage of Azerbaijani and Kazakh oil and Turkmen gas over their territories.

At the Summit of the Organisation for security and Co-operation (OSCE) held in November 1999 in Istanbul, the governments of Turkey, Azerbaijan and Georgia are due to sign an agreement that will include terms for seeking commercial investment in the development of an oil pipeline from Baku to the Turkish mediterranean port of Ceyhan. Those three governments and Turkmenistan have also signed an agreement on a pipeline to deliver gas across the Caspian Sea from Turkmenistan and into Turkey. Both agreements on pieplines were supported by the USA.

However, some influential figures in Turkey believe Russia and Iran should not be isolated. In fact, they accept the necessity of the Baku-Ceyhan oil pipeline project which should avoid dependence on Russia and Iran for energy supplies. They (some influential figures) warn simultanously that Turkey should also avoid to be provocative to Russia and Iran. That means Turkey should also support the still constructing natural gas pipeline projects with Russia (the so-called Blue Stream project) and Iran (this is also still in construction). This should also be necessary for a balance between drei states in the region in order to avoid any confrontation on the issue. Especially, isolating Russian enterests in the region would lead Turkey to be absolut 
dependent on the US (in other words, an only US enterests limited Turkish energy policy would bring Turkey in an absolut dependence on the USA. Such a policy would threat the peace in the region.

The realisation of these projects plays an important role in the future of the $\mathrm{ECO}$, both with regard to creating closer economic relations between the ECO members and with regard to the establishment of an equilibrium between the powers of the region. The strategic importance of the region will increase an account of the oil and natural gas pipelines and the protection of political stability in Central Asia and the Caucasus will be the western world's problem beside the countries of the region.

The fact that Turkey is on these transportation routes has significance with regard to the provision of energy to the EU and will be helpful in decreasing dependence on Middle-East resources controlling the prices more easily

According to this energy policy which is also valid for the US, like in the Baku-Ceyhan project, the US wants the new pipelines to pass outside Russia and Iran. A special importance is attributed to Turkey in the energy policies of US regarding this region. Therefore, Turkey's natural gas projects with Russia and Iran are not contradictory to the energy policies of US. Turkey imports natural gas from various countries in order to satisfy its constantly increasing energy needs and it must be evaulated in view of its own interests.

The paths followed by the ECO have been pursued by other regional organisations with disappointing results. Establishing a free trade area by piecemeal steps based on offers of preferential treatment has never been successful. The more successful implementations of free tarde areas or Customs Unions over the past 40 years, such as the EEC and EFTA, have involved across-the-board elimination of tariffs according to a set timetable, with little scope for expectations or delays. It is doubtful whether the ECO members are prepared for such a major initiative, but the more limited ECO protocol on preferential tariffs is unlikely to be a practical alternative.

A major difference between the ECO and the other regional groupings is the poorly developed transport networks (both road and railway) within such a continental organisation and seven new members are all landlooked countries. In spite of the cultural and linguistic similarities which exist, Turkey does not have a common border with any of the new Turkic republics (with the exception of the autonomous republic of Nakhichevan, which itself is geographically separate from Azerbaijan). This makes transport and other links more precarious, all the more so as such routes have to pass through either Armeina or Iran to reach Turkey. Moreover, Turkey is located at the 
Western and of the belt of new republics. While this makes Turkey a plusible route for land transit links to Europe, it is not necessarily always the most attractive. In particular, the republics are incresingly finding diversification of supply routes southwards to reach seaports in Iran and Pakistan a cheaper and therefore in some cases a more atrractive option. The most promising recent development has been the completion of the railway between Turkmenisan and Iran, which forms the first connection between the former Soviet rail network and line to an Indian port.

However, lieve the lack of physical infrastructure out of consideration, the crucial reason wyh trade has been toslow to develop lies in the "similar nature of the national economies" of the new members of ECO and the founding members in this regional grouping. Although most of those members can be considered semi-industrialised economies, they have a narrow base of export competitiveness, concentrated on primary products or textiles and clothing. Oil and natural gas dominate the exports of the new members of ECO and Iran. During the Soviet era, the Central Asian republics' agriculture became a monoculture devoted to cotton, which is the major export of some central Asian countries such as Uzbekistan. Cotton is also the biggest primary product export of Pakistan and Turkey, manufactured exports are more important than primary products, but in both countries, there is a heavy concentration on textiles and clothing.

The prospects for intra-regional trade based on the ECO members' current export bundles are limited. Turkey has the most diversified exports and could exchange manufactured goods for primary products from other ECO members. Especially, in the case of energy, Turkey is a good buyer of oil and natural gas from ECO members. Therefore, the value of trade between Turkey and the newly independent members of ECO seems to be growing, if the Baku-Ceyhan oil pipeline and the three natural gas pipelines from Turkmenistan, Russia and Iran into Turkey would be realised. From the side of Turkey, in order pay the imported oil and natural gas, Turkish construction firms would be more active in building of facilities such as factories, bridges, highways and airports as it has been similar between Turkey and Russia for paying Russian natural gas since the 1990s. today, a large number of Turkish companies are active in yhose countries in various fields especially in service sector, they employs there tausend workers, engineers and Technicians in Russia and less in the newly independent members of ECO.

Familiarity with local culture is an important advantage for Turkish businessmen compared to Western companies. There is still much more scope for co-operation between Turkish and Western companies in Central Asia with 
the West providing much needed capital and Turkish firms offering quality labour at a reasonable price. However, the negative side of this relation is Turkey's not having all the economic means expected by the Central Asian republics. Concerning the economic and trade relations on the one hand, the multilateral cooperation in cultural and educational matters on the other hand, there also seemed, initially, a danger that Turkey was tempted to act as "big brother" toward the Turkish states, though they had just escaped the clutches of another big brother.

An important problem for Turkey in exploiting its new relationships to the east is the presence of other competitive regional powers. There was great euphoria in Turkey when the Turkish states in Central Asia and Azerbaijan in the Caucasus secured independence from Moscow in late 1991. The Turkish government had high hopes of establishing close ties, making Turkey a leading actor in post-Soviet Central Asia. Western governments encouraged Turkey to become actively involved out of fear that Iranian-inspired religious radicalism would otherwise take hold. However, influence of Russia and Iran on these Turkic republics cannot be overlooked. Russian population represents a part of population in those republics although the population number of Russians is variable from country to country.

Concerning the so-called "bridgetheory" it can be said that, at least in the case of energy, Turkey may be an "energy bridge" between the West and the Turkish republics, even if it seems to be exaggerated that Turkey can play a role of a "bridge" between these republics and the West. This is why Turkey is not only a buyer of oil and natural gas but also the rest of these natural resources which Turkey does not consume will be exported from the Turkish Mediterranean port.

In conclusion, some members countries hope that a larger internal market could encourage new activities within the ECO. However, preferential tariff reductions face the problem of overlapping regional organisations. In January 1996, Turkey formed a Customs Union with the European Union, which limits its ability to change tariff rates. In addition to the ECO, Turkey is a member of i) Organisation for Economic Co-operation and Development (OECD), ii) the Black Sea Economic Co-operation (BSEC), iii) the Organisation of Islamic Conference (OIC), iv) the Developing-8 (D-8). Pakistan is a member of the South-Asian Association for Regional Co-operation, although that regional organisation has a little impact on its trade policies. Kazakhstan, Kirghizstan and Uzbekistan signed a Customs Union agreement in 1994, and together with other former Soviet republics are involved in negotiations over an Euro-Asian economic union. Kazakhstan and Kirghizstan signed a Customs Union with the Russia and Belarus. 


\section{Appendix I}

In dealing with the ECO project it is interesting to look at other regional economic organisations of which Turkey is alsoa member.

a) Organisation for Economic Co-operation and Development (OECD): Turkey became a member of the OECD in April 1948 (then the European Economic Co-operation Organisation). This organisation aimed to rebuild the economies of member countries and establish liberal foreign trade policies between them. The organisation quickly expanded, taking in further members from outside Europe.

b) European Union (EU): After the establishment of the European Economic Community on January 1, 1958, Turkey began negotiations with the EU and signed the Ankara Agreement in 1963. Under the Ankara Agreement, Turkey is an associate member of the EU with the aim of full membership when Turkey has met all necessary criteria. Since January 1,1996 , Turkey has been in a Customs Union with the EU. At the EU Summit held in Helsinki on 10-11 December 1999 Turkey was also announced as one of 13 candidates for full membership of the EU. ${ }^{44}$

c) Organisation of the Islamic Conference (OIC): The OIC is a group of 51 Islamic states and was established to promote and strengthen Islamic solidarity and to consolidate co-operation among member states in economic, social, cultural, scientific and other vital field of activity so as to ensure the socioeconomic welfare of the 1.2 billion Muslims in the world. When the OIC was founded in 1969, it was mainly intended as a political organisation whose main objective was to strengthen Islamic solidarity. But even in the early days of its existence, $\mathrm{OIC}$ member countries began to feel a strong need for the establishment, promotion and expansion of economic co-operation amongst themselves.

Islamic countries hold $19 \%$ of the world's land, $13 \%$ of the world's arable and productive land, of which only $6 \%$ is subject to irrigation. Furthermore, the application of modern technological facilities is very limited. For example, in 1991 the number of tractors in 47 Islamic countries was fewer than 1.5 million (5\% of the world total figure and half of which was being operated in Turkey). A similar situation was apparent in the use of other operational inputs such as insecticides, chemicals and pesticides. Since half the Islamic countries are badly afflicted by hunger and poverty they must divert more resources to the agricultural sector and food security areas. ${ }^{45}$

The gloomy picture of the Islamic countries can also be observed from National Income statistics. Average per capita income in the industrialised 
countries was over $\$ 15,000$ in 1992 and $\$ 3,000$ world-wide, whereas in the Islamic countries, taking into account oil producer countries, it was just $\$ 2,000$. Closer analysis shows that among Islamic countries only four oil producing countries (Brunei, UEA, Qatar and Kuwait) were in the high income group, and other oil producing nations (Saudi Arabia, Bahrain, Oman, Libya, Malaysia) were in the upper middle income economies. Turkey was in the lower band of middle income countries. Thirty of them were in the lower income band, of which 20 were known as the poorest nations in the world with less than $\$ 500$ per capital income. ${ }^{46}$

Since 1974, Turkey's economic and commercial relations with the OIC members have been growing steadily. For geographical reasons, Turkey's relations with these countries were initially concentrated on its ties with the Middle East. But, in recent years, these ties have extended to the remaining OIC countries. This co-operation has been through the development of multilateral, as well as bilateral, relations. Turkey's co-operation with the OIC countries has gained further dynamism through hosting the Seventh Islamic Conference of Foreign Ministers in Istanbul in 1976. Since then, Turkey has played an increasingly important role in the economic activities of the OIC, especially in the economic and financial spheres.

Turkish trade with the OIC countries has been affected by three major events since 1980s:

- the internal structural adjustment and stabilisation programme, put into effect on 24 January 1980, which induced a liberal economy and trade which resulted in an export boom in the 1980s;

- the Iran-Iraq War, which increased trade between Turkey and Iraq, although Turkey kept a very careful balance in trade with Iran, under its neutrality vis-à-vis the war in question; and

- The Gulf War, which negatively affected Turkey's trade relations with the OIC countries.

Although the absolute value of Turkish exports to the OIC countries has expanded since the 1980 s, the corresponding share of trade of these OIC countries did not follow the same pattern. The share of the OIC members in total Turkish exports was 19.3 per cent in 1980 . It immediately increased to 36.2 per cent in 1981. Since then it continued to decline, averaging at 18-22 per cent during 1990 s. ${ }^{47}$

The trade expansion was consolidated by an increase in construction contracts. From 1976, an increasing number of Turkish firms put in bids and 
were aẃarded contracts in the Middle East, particularly in Iraq, Libya and Saudi Arabia, as a result of the orientation of incresing oil revenues to the construction sectors of these countries. As of the end of 1981, the value of tenders awarded to Turkish companies totalled $\$ 9$ billion. By June 1988, the value of construction contracts awarded to Turkish firms reached $\$ 16.9$ billion. ${ }^{48}$

Parallel to the progress in construction services, Turkish exports of labour to the oil producing Arab countries increased from 1976, especially to Saudi Arabia and the other Gulf countries, providing employment opportunities to a significant number of Turkish workers and technicians. The size of the Turkish labour force in those countries was around 250,000-350,000 at the end of 1995. This has been an important source of foreign exchange and employment for Turkey. ${ }^{49}$

Clearly then, Turkey's trade with OIC members depends to a great extent on the conjuntion of conditions such as the war between Iran and Iraq and the Oil Schock. Therefore, the possibility of stable commercial and economic relations with OIC countries is limited. The Gulf War constitutes a good example in this context.

From the beginning of the Gulf conflict - the invasion of Kuwait by Iraq Turkey sided with the Western Powers. Despite the large volume of trade with Iraq, and the fact that a pipeline carrying Iraqi oil to the Mediterranean passes through Turkey, Turkey was one of the first countries to join the U.N. economic embargo. Direct and indirect costs of the Gulf Crisis have been a tremendous burden on the Turkish economy. Even the most concervative estimates of the direct costs due to the loss of trade, construction and transportation put this burden at around \$8-12 billion [per annum]..$^{50}$ The aid to Turkey after the crisis covered only a small portion of Turkey's loss and is far from easing the economic burden placed on Turkey in the aftermath of the crisis.

Furthermore, Turkish workers working in oil producing Arab countries are generally employed by Turkish construction firms in charge of infrastructural projects. In other words, their employment is dependent on the duration of these projects. Therefore, many of these workers face poor working conditions with low wages and little social protection compared to Western standards.

\section{Concluding remarks}

i) Turkey is a secular state. In this respect, it may be asked why Turkey as a secular state has been participating in a regional co-operation organisation such as the OIC the foundation of which is based on religious commonality, namely Islam. The reason is that the economic problems in the mid-1970s forced Turkey to intensify its economic relations with the OIC. 
In particular, two economic factors played an important role in joining the OIC. The first of these two factors was the imperative to increase foreign trade volume with OIC members. At that time, Turkey's foreign trade volume was low and the OIC market held promise for Turkish exports (especially for Turkish agricultural products). Second was the emergence of the oil crisis during the 1970s, which led Turkey to establish closer ties with the oil producing Arab countries. These factors help us to better understand how the oil crisis and consequental increases in prices affected Turkey, especially in the context of the fact that total sum of Turkish export earnings in 1974 was not sufficient to cover even the cost of oil imports alone.

ii) Turkey as a secular state cannot intensify its relations with OIC members, politicallybecause, since the reforms of Kemal Atatïrk, Turkey's western orientation has been regarded as irreversible. A key factor in this respect was the fact that a country country with an Islamic character adopted the Western model of secularism, (that is, the separation of religious institutions and issues from the institutions of state), thus enabling a politico-culture mutuality of interests despite the diverging religious character of the country.

This secular character hindered the Turkish state in its efforts to develop political relations within the OIC of which most countries are ruled according to Islamic principles. Furthermore, as the example of Turkey's coalition government of 1996 (in which the religious orientated Welfare Party was the leading party) shows, the Turkish military regards itself as the guardian of Atatürk's reform and of the secular state. The army refused to tolerate the religious orientated activities of that government and forced it to resign in 1997. Without question a large part of Turkish society which had always respected Islam but opposed establishing any religious system in Turkey supported the reaction of the military on that occasion. One of the more controversial policies of the Welfare Party was the proposal to replace the previous policy of western orientation with a stronger move toward the Islamic world. There was talk of pulling out of NATO and terminating the Customs Union with the European Union as well as of creating an Islamic common market were the reasons to remove this party from the government. That wa why Welfare was removed from office. The D8 movement, which is explained below, may be regarded as a good example of the Wlfare Party's proposals.

d) The D (Developing) - 8 Group: The D-8 was a Welfare Party initiative, and the issue goes to the heart of the reasons for the slow progress achieved in the OIC. The Welfare Party tried to form a new organisation which would resemble the G-7 of the West. After extensive deliberations, the heads of state and government of Bangladesh, Egypt, Indonesia, Iran, Malaysia, Nigeria, Pakistan and Turkey met in Istanbul on June 15, 1997 and signed an agreement 
that gave birth to D-8. The D-8 was launched as an effort to raise the voice of the Islamic countries in global trade and economic platforms which they believe were dominated by western economic groups. The D-8 declaration proclaimed "deep disappointment" with the "old policies of double standards, discrimination and oppression" that continued in the post-cold war era.

According to the Istanbul Declaration signed at this Summit, the main objective of the D-8 was to promote socio-economic development in accordance with the following principles:

- peace instead of conflict;

- dialogue instead of confrontation;

- co-operation instead of exploitation;

- justice instead of double-standards;

- equality instead of discrimination; and

- democracy instead of oppression..$^{51}$

The Istanbul Declaration clearly stated that this initiative would be a forum with no adverse effects on bilateral and multilateral economic and trade commitments of the member states involved. Furthermore, the forum was to be open to other developing countries subscribing to the goals, objectives and principles of the group and sharing common bonds.

Six initial D-8 projects were identified, including the establishment of an industrial and technological data bank and joint venture schemes in Islamic insurance, agriculture and aircraft industries.

The main activity of the D- 8 would be carried out by the private sector in the member countries where the governments' main task was to create an environment conducive to such action. The Istanbul Declaration encouraged the establishment of a Joint Business Council among the Chambers of Commerce and industry and other related bodies of the member countries with a view to initiating action oriented projects.

The D-8 would have a rather loose organisational structure. The Summit, the Council and the Commissions would meet once or twice a year. No permanent bureaucratic structure was envisaged. Only an Executive Director was to be appointed to coordinate the overall activity of the D- 8 and he would be resident in Istanbul.

\section{Concluding remarks}

i) The D-8 movement was based on the common religious orientation of its members. In this respect, it should be asked why Turkey, which adopted 
Western secularism supports such a economic co-operation project among the Islamic countries. The reason for that is as follows: on 8 July 1996, the coalition government formed by the religiously orientated Welfare Party led by Necmettin Erbakan and the concervative True Path Party led by Tansu Ciller formed a coalition government in the Great Turkish National Assembly. Erbakan had achieved his goals. He was Prime Minister, and, for the first time in the Republic's history, a party uncommitted to the traditions of Atatürk had become the leading power in government. The Welfare Party's assumption of the power of government caused considerable irritation among Turkey's western allies and among the Western orientated groups of the Turkish elite. Starting from 1997, after a short time of forming of coalition government, through the reaction of democratic opposition and especially the pressure of the military, Prime Minister Erbakan was forced to resign in mid-1997. A short time later, the Welfare Party was abolished by the Constitutinal Court. Since then, the D-8 Movement has lost its significance.

ii) There are no leading states in terms of economic or financial power in the movement..$^{52}$ Although Turkey provided the political leverage to sustain the movement in the beginning, the political conjunction has changed considerably since then. After Erbakan's coalition government fell from power, the D-8, initiated as it was by Islamist ideology, is not among the priorities of more recent Turkish governments. The other members of the D-8 movement are not in a position to lead in furthering co-operation.

iii) The D-8 countries are mostly underdeveloped or developing countries and they mostly import industrial and high-technology goods from developed countries. These trade patterns cannot be replaced by countries within the D8 since they are all importers of such goods. How complementary are the D8 economies? Although most members may be regarded as semi-industrialised economies, they have a narrow base of export competitiveness, concentrated on primary products or textiles and clothing. Oil dominates the exports of Iran, Nigeria and Indonesia. Cotton is important for Turkey, Egypt and especially for Pakistan. For these countries, manufactured exports are more important than primary products but there is a heavy concentration on textiles and clothing. The prospects for intra-regional trade based on the D-8 members' curent export bundles are limited.

iv) Other than this, no commonality exists between D-8 members. Since Turkey may be regarded as a European country, the D-8 members belong to three continents. It is obvious that great economic, social, cultural and political disparities exist among the members. Sustaining effective cooperation among such vastly differing countries does not seem to be a realistic aim. ${ }^{53}$ 
e) Black Sea Economic Co-operation (BSEC): Established in 1992 with Albania, Bulgaria, Romania, Moldova, Ukraine, Russia, Georgia, Azerbaijan, Armenia, Turkey and Greece.

The BSEC, with a total population of 325 million is rich in natural resources and covers some 20 million square kilometres. It is a market with huge potential. Nine of the 11 BSEC member states are former socialist countries which have, at present, no stable or powerful political systems. Neither is there a relationship of trust between these states. Economically, BSEC countries have problems typical of the transition process from a socialist to a market economy. The European Union is the main focus of attention for most of the western BSEC states' aspirations. They believe that the success of the transition process depends on the support of the West and, especially, Europe. The BSEC countries recognise that the success of their transition depends on two factors:

- the success of national reform programmes; and

- Europe's willingness and ability to invest in their economies.

The EU is interested in the BSEC because the BSEC area is of great importance for the transport of oil and for accessing the huge energy resources of the Caspian Sea. ${ }^{54}$ 


\section{Appendix II}

\section{Treaty of Izmir}

The Governments of Islamic State of Afghanistan, Azerbaijan republic, Islamic republic of Iran, Republic of Kazakstan, Kyrgyz Republic Islamic Republic of Pakistan, Republic of Tajikistan, Republic of Turkey, Turkmenistan and republic of Uzbekistan:

Bearing in mind the Treaty of Izmir originally signed at Izmir, Turkey, on 12 March 1977 by Iran, Pakistan and Turkey and amended in 1990 and 1992 as the basic Charter of the Economic Cooperation Organisation (ECO);

Conscious of the deep-rooted historical and cultural ties among the peoples of their Countries;

Recognizing that peace and stability constitute one the pre-requisite for economic cooperation;

Reiterating their commitment to the U.N. Charter, the purposes and principles of which provide the basis for fruitful cooperation amongst all peoples;

Resolved to ensure the economic and social progress of the ECO Member States;

Determined to bring the Economic Cooperation Organization into conformity with its enhanced role;

Reaffirming their determination to pursue regional economic cooperation on the basis of the common needs of their countries and in the light of the changes taking place on the global economic scene which have a bearing on ECO Member States;

Have decided to revise the provisions of the Treaty of Izmir as the Charter of the Economic Cooperation Organization and to this end have designated their Plenipotentiaries who having exchanged their Full Powers, found in good form, have agreed on the following Articles:

\section{Article - I}

\section{Definitions}

In this Treaty, unless the context otherwise requires:

(a) "Organization" means the Economic Cooperation Organization which may also be referred to as "ECO.

(b) "Member States" means the Member States of the Economic Cooperation Organization. 
(c) "Observers" means States/Organizations which are granted Observer Status by the Economic Cooperation Organization.

(d) "Dialogue Partners" means States/Organizations with which ECO enjoys consultative relationships in agreed areas of common interstest.

(e) "ECO region" means the territories of the Member States.

(f) "Treaty" means the Treaty of Izmir.

(g) "Summit" means the Meeting of the Heads of State/Government of ECO Member States.

(h) "Council of Ministers" means the Council of the Economic Cooperation Organization.

(i) "Council of Permanent Representatives" means the Council of Permanent Representatives of the Economic Cooperation Organization.

(j) "Regional Planning Council" means the Regional Planning Council of the Economic Cooperation Organization.

(k) "Specialised Agencies" means the organs of ECO established by the decision of the Member States with legal personality and autonomy in management to promote close cooperation among themselves in social, cultural, technical and scientific fields in coordination with ECO Secretariat.

(1) "Regional Institutions" means economic, commercial and financial organs of ECO with self-sustained budget, legal personality and autonomy in management to promote economic growth of the ECO region through provision of financial and commercial facilities and investment of funds within the region.

(m) "Secretariat" means the the Secretariat of the Economic Cooperation Organization located in Tehran which may also be referred to as "Headquarters".

(n) "Secretariat-General" means the Secretary General of the Economic Cooperation Organization.

(o) "Host Country/Government" means the Country/Government of the Islamic Republic of Iran. 


\section{Article - II: Objectives}

The objectives of the Organization shall be:

(a) To promote conditions for sustainable economic development and to raise on this basis the standard of living and quality of life in the Member States through mobilization of economic and social potentials of the region.

(b) To take measures towards progressive removal of trade barriers within ECO region and expansion of intra and inter-regional trade, keeping in view experiences in other regions and global economic trends.

(c) To pursue, in line with the basic aspirations of the Member States, increased economic cooperation in order to secure greater role and contribution of ECO region to the growth of world trade and removal of iniquitous trading policies resulting in adverse terms of trade for the developing countries, particularly for the Member States.

(d) To provide for gradual and smooth integration of the economies of the Member States with the World Economy to ensure their fuller participation in the globalizaiton process.

(e) To promote active regional collaboration and mutual assistance in economic, social, cultural, technical and scientific fields.

(f) To accelerate development of transport and communications infrastructures linking the Member States with each other and with the outside world.

(g) To promote integration of public and private sector activities with emphasis on economic liberalization and privatization towards increased participation of the private sector in the regional economic development through joint ventures and investments.

(i) To develop joint programmes for human resource development in ECO region.

(j) To intensify mobilization and utilization of ECO region's natural resources in particular energy resources.

(k) To enhance efforts for effective utilization of the agricultural and industrial potentials of ECO region.

(1) To develop regional cooperation to eradicate drug abuse. 
(m) To facilitate cooperation in the fields of ecological and environmental protection within the region.

(n) To promote mutually benefical interaction and cooperation between $\mathrm{ECO}$ and other regional and international organizations as well as financial institutions.

(o) To further strengthen historical and cultural ties among the peoples of the ECO region as well as exchanges in the field of tourism.

\section{Article - III: Principles of Cooperation}

Regional cooperation within the framework of this Treaty shall be based on the following principles and policies:

(a) Sovereign equality of the Member States which shall fulfil, in good faith, the obligations assumed by them under this Treaty, based on mutual advantage, without prejudice to their bilateral and international obligations.

(b) Linking of international economic development plans with ECO's immediate and long-term objectives to the extent possible.

(c) Joint efforts to gain freer access to markets outside the ECO region for the raw materials and finished products of the Member States.

(d) Effective Utilization of ECO institutions, agreements and cooperative arrangements with other regional and international organizations including multilateral financial institutions.

(e) common endeavors by the Member States to develop a harmonized approach, in order to enhance their participation in regional and global arrangements.

(f) Cooperation among Member states in pursuance of strategies based on realistic and gradualistic approaches, taking into account the existing potentials and resources within ECO as well as differences in the levels of Member States' economic development with due regard to the agreements and arrangements made with other regional and international institutions.

(g) exchanges in educational, scientific, technical and cultural fields. 


\section{Article - IV: Meeting of the Heads of State / Government}

The Heads of state/Government of the Member States shall meet biennially or more often if considered necessary by the Member States. The summit meetings shall review the objective conditions and progress in implementation of ECO programmes and projects and shall also serve as the highest-level forum for exchange of views on regional and global issues of common interest to the ECO region.

\section{Article - V: Organizational Structure of ECO}

There shall be, as the principal organs of ECO, a Council of Ministers, a Council of Ministers, a Council of Permanent Representatives, a Regional Planning Council, a Secretariat and Specilized Agencies in specific fields of cooperation. Regional institutions and ad-hoc committees may also be established by the decision of the Council of Ministers.

\section{Article - VI: Council of Ministers}

The Council of Ministers shall be the highest policy and decision-making body of ECO. It shall comprise the Ministers of foreign Affairs of the Member States or any other representative of full ministerial rank as may be nominated by the governments and shall meet at least once a year by rotation, in the territories of the Member States. Extraordinary sessions of the Council may also be held either in the territories of the Member States or elsewhere by mutual agreement among the Member States. The Council of Ministers may, if deemed necessary, propose the convening of meetings of other Ministers in the formulation of plans and projects in their respective fields through sectoral or joint ministerial meetings.

\section{Article - VII: Council of Permanent Representatives}

The Council of Permanent Representatives shall be a permanent body which, except when the Council of Ministers is in session, shall be responsible, on behalf and in the name of the Council of Ministers, for carrying out its policies, for formulating issues rerquiring decisions by the Member States and for taking appropriate steps on matters connected with the implementation of the decisions of the Council of Ministers. It shall comprise the Permanent Representatives/Ambassadors accredited to ECO. It shall meet as often as necessary under the chairpersonship of the Council of Ministers.

\section{Article - VIII: Regional Planning Council}

The Regional Planning Council shall comprise the heads of the Planning Organizations of the Member States and/or such other representatives of corresponding authority 
as may be nominated by their governments and shall meet at least once a year prior to the annual meeting of the Council of Ministers under the chairpersonshipof the representative of the Member State holding the chairpersonship of the Council of Ministers at the headquarters of the Organization. The Regional Planning Council shall evolve programmes of action for realizing the objectives of the Organization alongwith a review of past programmes and evaluation of results achieved to be submitted to the Council of Ministers and in this task shall be assisted by the Secretariat. It may propose to the Council of Ministers the establishment of regional institutions and ad-hoc committees in priority areas of cooperation.

\section{Article - IX: Secretariat}

1. The Secretariat shall comprise a Secretary-General and such staff as the Organization may require. It shall function with its Headquarters in Tehran and in accordance with the provisions of the Agreement between the Government of the Islamic Republic of Iran and Economic Cooperation Organization (ECO) relating to the Rights, Privileges and Immunities of the ECO Secretariat approved by the Council of Ministers and signed between the Foreign Minister of the host country and the Secretary-General.

2. The Secretary-general shall be elected and appointed by the Council of Ministers for a non-renewable term of three (3) years from among the candidates nominated by the Member States on the basis of qualifications, experience and suitability as laid down in the Staff Regulations of the ECO Secretariat. As the Chief Administrative Officier of the Organization, he shall be responsible to the Council of Ministers for all activities of the Organization and shall hold the rank and status of Ambassador. He shall participate in the meetings of all Councils and shall perform such other functions as are entrusted to ihm by these organs. He shall make an annual report to the Council of Ministers on the work of the Organization.

3. The staff of the Secretariat shall be appointed and governed in accordance with the terms \& conditions and procedures laid down in the Staff Regulations established by the Council of Ministers. All staff members shall be considered full-time international civil servants receiving their emoluments from the budget of the Secretariat in accordance with the scales of salaries and allowances approved by the Council of Ministers.

4. The role of the Secretariat shall be to initiate, coordinate and monitor the implementation of ECO activities and to service the meetings of the Organization. The functions and the structure of the Secretariat shall be governed by the Staff Regulations of the ECO Secretariat approved by the Council of Ministers. 
5. In the performance of their duties, the Secretary-general and the staff shall not seek or receive instructions from any Government or from any other authority external to the Organization. They shall refrain from any action which might reflect on their position as international civil cervants responsible only to the Organizaiton.

\section{Article - X: Specialized Agencies and Regional Institutions}

There shall be specialized agencies and regional institutions in specific fields odf cooperation. The number, nature and objectives of these agencies and instituions may be determined by the Council of Ministers and revised as and when necessary. All specialized agencies and regional shall submit annual reports on their activities to the Council of Ministers in accordance with their Rules of Procedure and also notify the Secretary General of the Organisaiton.

\section{Article - XI: Financial Provisions}

The Secretariat shall have a centralized budget. The contributions in US dollars by Member States to this budget shall be decided by the Council of Ministers, taking into account their capacity to pay and the prevailing scale of assessment of contributions of the United Nations.

\section{Article - XII: Decision - Making}

1. All decisions on vital issues pertaining to the admission of new members or observers or dialogue partners, budgetary arrangements, matters with financial implications, appointment of the Secretary General, adoption of economic strategies and action plans, amendments to the Treaty and ECO's external relations or any other issues that the Council of Ministers may consider to be of viatl importance to the Organization, shall be taken on the basis of unanimity.

2. Decisions on other matters shall be taken on the basis of simple majority of the total membership of ECO provided that the remaining members choose to abstain and/or are not against the decision.

\section{Article - XIII: Membership}

1. Any State enjoying geographical contiguity with the ECO region and/or sharing the objectives and principles of ECO may apply to become a member of the Organization. Such State shall address its application through the Secretary General to the Council of Ministers which may decide the admission of a new member by a unanimous vote. 
2. The applying State shall undertake to fully respect and abide by the provisions of the present Treaty and shall accept all obligations arising therefrom. After the acceptance of its application for membership, the applying State shall accede to the Treaty in accordance with its constitutional rules and practices.

3. The Instrument of Ratification shall be deposited as soon as possible with the host government, Government of the Islamic Republic of Iran, which shall transmit a certified copy to the other Member States and to the Secretariat.

4. Pending such ratification the new Member State may, with the concurrence of the Council of Ministers, participate as a full member in the activities of all organs of ECO, and make its assessed contribution to the ECO budget.

5. Any Member State may at any time withdraw from the Organization by giving a formal notice of its intention to withdraw to the Secretary General who shall transmit such notice to all Members. The withdrawal shall take effect six months after such notice has been received by the Secretary General and all financial obligations due to theOrganization have been settled.

\section{Article - XIV: General Provisions}

\section{Legal Status}

1. The Economic Cooperation Organization shall enjoy in the territory of each of its Member States such legal capacity and privileges and immunities as may be necessaryfor the exercise of its functions and the fulfilment of its objectives under the conditions laid down in the Agreement on the Legal Status of the Economic Cooperation Organization (ECO), National Representatives and International Staff which shall be an annex to this Treaty.

\section{Official Language}

2. English shall be the official language of the Organization. Arrangements shall be made for unofficial Russian translation and interpretation.

\section{Rules of Procedure}

3. The meetings of the Organization at all levels shall be held in accordance with the Rules of Procedure to be approved by the Council of ministers.

\section{External Relations}

4. The Organization may establish cooperative relationship with other regional or international organizations, states and institutions. The nature and 
extent of such collaboration shall be determined by the Council of Ministers by a unanimous vote.

5. The Organization may grant observer or dialogue partnership status to other Regional or International Organizations, States and Institutions. The nature and scope of such status shall be determined by the Council of Ministers by a unanimous vote.

\section{Article - XV: Amendment}

1. The Government of any Member State may submit through the Secretariat to the Council of Ministers proposals for the revision or amendments to the present Treaty.

2. Upon approval by the Council of Ministers, the consequential revision and amendments shall come into force after two-third of the Member States deposit their instrument of ratification in accordance with their respective constitutional rules and practices.

\section{Article - XVI: Final Provisions}

1. The present Treaty shall be ratified in accordance with the respective constitutional rules and practices of Member States and the instruments of ratification shall be deposited with the Government of the Islamic Republic of Iran.

2. The present Treaty shall come into force after two-third of the Member States deposit the instrument of ratification with the Islamic Republic of Iran.

3. The present Treaty after entering into force shall supersede the original Treaty of Izmir of March 1977 and the Protocols of 1990 and 1992.

4. The present Treaty is drawn up in one original copy in the English language. 


\section{Endnotes}

${ }^{1}$ Haghayeghi, M. (1995), "Economic Cooperation Organization: A Preliminary Assessment", Central Asia Monitor, No. 1, p. 14.

${ }^{2}$ De Cordier, B. (1996), "The Economic Cooperation Organization: towards a new silk road on the ruins of the Cold War?", Central Asian Survey, Vol. 15, No. 1, p. 47.

${ }^{3}$ Haghayeghi, M. (1995), p. 15.

${ }^{4}$ De Cordier, B. (1996), p. 48.

${ }^{5}$ Togan, S. (1993), "Black Sea Economic Co-operation Organisation, Turkic Republics and Turkey: Possibilities for Regional Economic Integration", This paper was presented to the Syposium for European Union/Turkey/Euroasia: New Trends in EU-Turkey Cooperation, organised in Istanbul, September 22-24, 1993, by Marmara University European Community Institute and TEPSA (Trans European Policy Studies Association). p. 3.

${ }^{6}$ De Cordier, B. (1996), p. 49.

${ }^{7}$ Ibid. p. 50.

${ }^{8}$ Ibid. p. 51.

${ }^{9}$ Togan, S. (1993), p. 7.

${ }^{10}$ De Cordier, B. (1996), p. 51.

11 Halbach, U. (1993), "Usbekistan: Konflikte in der zentralasiatischen Schlüsselregion", Vierteljahresberichte - Problems of International Cooperation, No. 131, March, p. 53.

${ }^{12}$ De Cordier, B. (1996), p. 51.

${ }^{13}$ Ibid. p. 51.

${ }^{14}$ Ibid. p. 53.

${ }^{15}$ Goetz, R. (1997), "Political Spheres of Interest in the Southern Caucasus and in Central Asia", Aussenpolitik, Vol. 48, No. 3, p. 257.

${ }^{16}$ Ibid. p. 258.

${ }^{17}$ For more details, see Sakwa, R. and Webber, M. (1999), "The Commonwealth of Independent States, 1991-1998: Stagnation and Survival", Europe-Asia Studies, pp. 379-415. / Zagorski, A. (1994), "Reintegration in the Former USSR?", Aussenpolitik, Vol. 45, No. 3, pp. 263-272.

${ }^{18}$ Reinvesting the CIS: Putin Takes the Helm, 2000/012100. ASP, 21 January 2000. 
19 Wihbey, P. M. (1999), "The southern Eurasian great game", Insight Turkey, Vol. 1, No. 2, pp. 48-51.

${ }^{20}$ Ibid., p. 55.

${ }^{21}$ Ibid., p. 56.

${ }^{22}$ Beddoes, Z. M. (1998), "Central Asia: A Caspian Oil", The Economist Survey, February $7-13$, p. 7.

${ }^{23}$ Wihbey, P. (1999), pp. 66-67.

${ }^{24}$ Bekar, O. (1998), "Turkish-Russian Relations", Centre for Intercultural Dialogue and Cooperation (Cidc) Insight Turkey, No. 22, p. 14. / see also Uludağ, R. (1999), "Türkiye'de Bavul Ticareti ve Ülke Örnekleri", Dünya, January 28. / Acar, Ö. (1999), "Rus Diş Ticaretinde Türkiye 2. Ortak",Cumhuriyet, November 4.

${ }^{25}$ Özügergin, \$. (1998), "Türkiye-Rusya ve BDT Ekonomik İlişkileri", Egevizyon, Vol. 5, No. 21, p. 19.

26 Dünya (1999), "Türkiye'nin Doğalgaz ihtiyacı artıyor", December 1.

${ }^{27}$ Foreign Economic Relations Board (DEIK) (1998), Central Asian Republics and the Republics of Azerbaijan, June, Istanbul.

${ }^{28}$ Aray, O. and Eyyüboğlu, B. (1998), New Independent States of Inner Asia and Turkey's Policy, research paper of the National Policy Research Foundation, presented to the Symposium for Inner Asia in the $21^{\text {st }}$ Century, held on 3-4 December 1998, Istanbul. / Brzezinski, Z. (1997), The Grand Chessboard-American Primacy and Its Geostrategic Imperatives, Harper Collins Pub., NewYork.

${ }^{29}$ Fuller, G. E. (1993), "Turkey's New Eastern Orientation", in Fuller, G. E. and Lesser, I. O. (eds.), Turkey's New Geopolitics: From the Balkans to Western China, Westview Press, Boulde/San Francisco/Oxford, p. 73 / see also Freitag-Wirminghaus, R. (1995), "Die Politik der Türkei in Zentralasien und Azerbaidschan", in Gumpel, W. (ed.), Deutschland und die Türkei: Gemeinsame Interessen in Europa, im Mittleren Osten und in Mittelasien, Deutsch-Türkische Konferenz der Südosteuropa-Gesellschaft und des Instituts für Aussenpolitik (Ankara) am 8. Und 9. Juni 1995 in München, Aus der Südosteuropa-Forschung, Vol. 7, p. 87.

${ }^{30}$ Harrison, G. W. / Rutherfold, T. F. / Tarr, D. T. (1996), Economic Implications for Turkey of a Customs Union with the European Union, Policy Research Working Paper 1599, International Economics Department, International Trade Division, The World Bank. p. 2.

${ }^{31}$ Ibid., p. 2.

${ }^{32}$ Bayar, A. (2000), Gümrük Birliğinin Türk Ekonomisine Etkileri, published by the Economic Development Foundation (IKV) in Istanbul, p. 37. 
33 Pomfret, R. (1999), Central Asia Turns South?: Trade Relations in Transition, Central Asian and Caucasian Prospects, published by The Royal Institute of International Affairs, pp. 6-15.

${ }^{34}$ Ibid., pp. 31-45 / Pomfret, R. (1997), "The Economic Cooperation Organization: Current Status and Future Prospects", Europe-Asia Studies, Vol. 49, No. 4, pp. 657 667.

35 See, for example, Öğütçü, M. (1998), Türkiye'de Yeni Bir Ekonomik ve Ticari Diplomasi Stratejisine Doğru, published by the TÜSİAD (No. T/98-6/230), İstanbul, pp. 282-288 / Lesser, I. O. (1993), "Bridge or Barrier? Turkey and the West After the Cold War", in Fuller, G. E. and Lesser, I. O. (eds.), Turkey's New Geopolitics: From the Balkans to Western China, Westview Press, Boulde/San Francisco/Oxford, pp. 100104 / Forum Europe (1993), Partners for Growth New Trends in ECTurkish Co-operation, Conference in Partnership with the Union of Chambers of Commerce Industry and Commodity Exchanges of Turkey, held on 13 and 14 May, Brussels, pp. 51-69.

${ }^{36}$ Lorca, A. V. (1995), "Turkey: The Door to Central Asia", Eurasian Studies, p. 63.

${ }^{37}$ Stephen, F. and Boulton, L. (1999), "Pipeline dispute fuels west's fiery relations with Russia".

${ }^{38}$ Oruç, S. (1999), "Despite a dazzling ceremony, Georgian reservation towards BakuCeyhan still remain", Turkish Daily News, November 25.

${ }^{39}$ Kazaz, H. (1999) "Istanbul Protocol first solid step towards Baku-Ceyhan pipeline", Turkish Daily News, November 19.

${ }^{40}$ Turkish Daily News (1999), "After annex protocol, Blue Stream now awaits Duma ratification", November 30 .

41 Oylum, Ş. (2000), "Aydınlık Türkiye İçin Mavi Akım", Ekovizyon, No. 27, pp. 3638 / Erten, T. (1999), "Mavi Akım, zorlu proje I-I", Dünya, November 3-5 / Erten, T. (1999), "Enerji diplomasisi", Dünya, November 8 .

${ }^{42}$ Kramer, H. (1996), "Turkey under Erbakan: Continuity and Change towards Islam", Aussenpolitik, Vol. 4, No., p. 383.

43 Ibid., p. 384.

${ }^{44}$ For more details, see Drud Hansen, J. / Nielsen, J. U-M. (1997), An Economic Analysis of the EU, McGraw-Hill Publishing company, London / Stirk, P. (1996), A History of European Integration since 1914, published by Pinter, London / Miall, H. (1993), Shaping the New Europe, published by the Royal Institute of International Affairs, London. 
${ }^{45}$ Başar, H. (1998), "Economic Cooperation among Islamic Countries", in Aykaç, M. (ed.) Symposium on Orientation in Islamic Economics, published by Marmara University Economic Research Center for Middle Eastern and Islamic Countries, Istanbul, pp. 72-73.

46 Ibid. p. 73.

47 Illkin, S. (1997), "Turkey's Economic and Commercial Relations with the Islamic Countries within the Multilateral Framework", Zeitschrift für Türkeistudien, p. 234.

${ }^{48}$ Ibid. p. 240.

${ }^{49}$ Ibid. p. 241.

${ }^{50}$ Ibid. p. 241.

${ }^{51}$ Ibid. p. 242.

52 For more details, see Tuncer, B. (1997) "D-8'lerin Zirve Toplantısı", Radikal, June 15.

${ }^{53}$ Kalaycığlu, E. (1997), "Refahyol'un MD-8 Serüveni", Finansal Forum, January 9.

${ }^{54}$ For more details, see Dartan, M. (1999), "Black Sea Economic Co-operation (BSEC): Proposals and Problems with particular Reference to the EU", pp. 7-51. 